\title{
DERIVED REFERENCE DOSES FOR THREE COMPOUNDS USED IN THE PHOTOVOLTAICS INDUSTRY: COPPER INDIUM DISELENIDE, COPPER GALLIUM DISELENIDE, AND CADMIUM TELLURIDE
}

P. D. Moskowitz, N. Bernholc, M. P. DePhillips and J. Viren

July 6, 1995

\author{
Biomedical and Environmental \\ Assessment Group \\ Analytical Sciences Division
}

DEPARTMENT OF APPLIED SCIENCE

BROOKHAVEN NATIONAL LABORATORY UPTON, LONG ISLAND, NEW YORK $1197 \mathrm{3}^{\text {t" }}$ 


\section{DISCLAIMER}

This report was prepared as an account of work sponsored by an agency of the United States Government. Neither the United States Government nor any agency thereof, nor any of their employees, not any of their contractors, sub- contractors, or their employees, makes any warranty, express or implied, or assumes any legal liability or responsibility for the accuracy, completeness, or usefulness of any information, apparatus, product, or process disclosed, or represents that its use would not infringe privately owned rights. Reference herein to any specific commercial product, process, or service by trade name, trademark, manufacturer, or otherwise, does not necessarily constitute or imply its endorsement, recommendation, or favoring by the United States Government or any agency, contractor, or subcontractor thereof. The views and opinions of authors expressed herein do not necessarily state or reflect those of the United States Government or any agency, contractor or subcontractor thereof. 


\section{DISCLAIMER}

Portions of this document may be illegible in electronic image products. Images are produced from the best available original document. 


\section{DERIVED REFERENCE DOSES FOR THREE COMPOUNDS USED IN THE PHOTOVOLTAICS INDUSTRY: COPPER INDIUM DISELENIDE, COPPER GALLIUM DISELENIDE,.AND CADMIUM TELLURIDE}

Paul D. Moskowitz, Nicole Bernholc, Michael P. DePhillips, and John Viren

July 6, 1995

Prepared for:

Fraunhofer Institute for Solid State Technology Munich, Germany

Photovoltaic Energy Technology Division

U.S. Department of Energy

Washington, DC

Biomedical and Environmental Assessment Group

Analytical Sciences Division

Department of Applied Science

Brookhaven National Laboratory

Upton, NY 11973

DASTRIBUTION OF THIS DOCUMENT IS UNLIMITED (folh 


\section{CONTENTS}

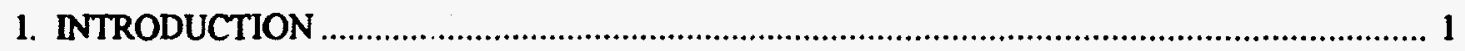

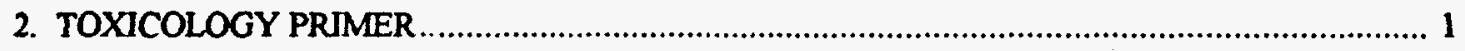

3. TOXICITY DATA FOR CIS, CGS, and CdTe

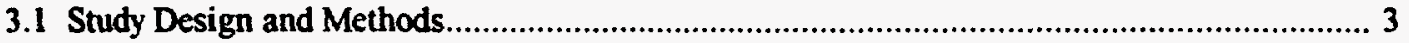

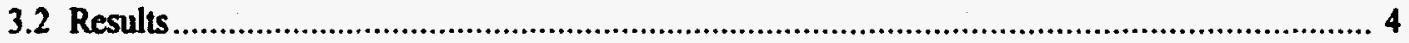

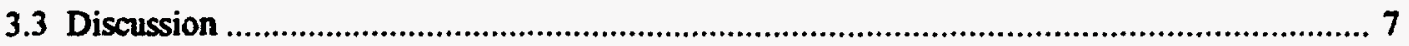

4. DERIVED REFERENCE DOSES FOR CIS, CGS and CdTe ............................................. 9

5. IMPLICATIONS OF THESE FINDINGS TO THE PHOTOVOLTAICS INDUSTRY .................11

6. REFERENCES

APPENDIX A - SUMMARY OF TOXICITY TESTING RESULTS FOR CIS, CGS, AND CdTe .......13

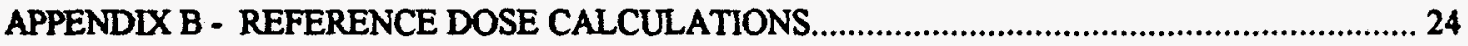

APPENDIX C - GLOSSARY OF COMMON TOXICOLOGY/RISK ASSESSMENT TERMS...........29

\section{TABLES}

A1. GROUP 1-Male Sprague Dawley Rats (CIS) ..........................................................................14

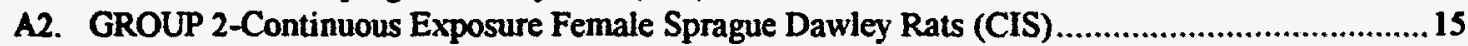

A3. GROUP 3-Gestational Exposure Female Sprague Dawley Rats (CIS) ...................................16

A4. GROUP 4-Pair Feeding Study Female Sprague Dawley Rats (CIS) .......................................17

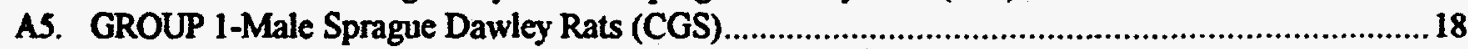

A6. GROUP 2-Continuous Exposure Female Sprague Dawley Rats (CGS) ..................................19

A7. GROUP 3-Gestational Exposure Female Sprague Dawley Rats (CGS) ....................................20

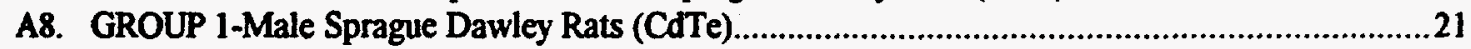

A9. GROUP 2-Continuous Exposure Female Sprague Dawley Rats (CdTe) ..................................22

A10. GROUP 3-Gestational Exposure Female Sprague Dawley Rats (CdTe) ..................................23

B1. Estimation of Reference Dose for (RfD) for Non-carcinogens with Example Calculation Based on CdTe.

B2. Summary Systemic Toxicity Used to Establish Lowest Observed Adverse Effect Level (LOAEL) from 28 Day Range Finding Study..

B3. Estimated Oral Reference Doses (RD's) for CIS, CGS, and CdTe Using Standard Uncertainty Factors (UF)

B4. Element-Specific Oral Reference Dose Projected from RfD's for Specific Compounds

FIGURES

1. Dose-response relationships 3

2. Schematic of the design used to evaluate the toxicity of CIS, CGS, and CdTe 


\section{INTRODUCTION}

Polycrystalline thin-film photovoltaic modules made from copper indium diselenide (CIS), copper gallium diselenide (CGS), and cadmium telluride (CdTe) are nearing commercial development. A wide range of issues are being examined as these materials move from the laboratory to large-scale production facilities to ensure their commercial success. Issues of traditional interest include module efficiency, stability and cost. More recently, there is increased focus given to environmental, health and safety issues surrounding the commercialization of these same devices. An examination of the toxicological properties of these materials, and their chemical parents is fundamental to this discussion. Chemicals that can present large hazards to human health or the environment are regulated often more strictly than those that are less hazardous. Stricter control over how these materials are handled and disposed can increase the costs associated with the production and use of these modules dramatically. Similarly, public perception can be strongly influenced by the inherent biological hazard that these materials posses. Thus, this report:

- Presents a brief background tutorial on how toxicological data are developed and used

- Overviews the toxicological data available for CIS, CGS and CdTe

- Develops "reference doses" for each of these compounds

- Compares the reference doses for these compounds with those of their parents

- Discusses the implications of these findings to photovoltaics industry.

\section{TOXICOLOGY PRIMER}

Toxicology is the study of the adverse effects of chemicals on living organisms (Klaassen and Eaton, 1991). In the United States, toxicological data are used by regulatory agencies for different purposes: The Food and Drug Administration (FDA) for admitting drugs, cosmetics, and food additives onto the market; the Environmental Protection Agency (EPA) for establishing acceptable environmental and public health exposures to chemicals; and, the Occupational Safety and Health Administration (OSHA) to ensure that safe conditions exist for workers in the workplace. These objectives can only be reached if exposures are defined that do not entail an unacceptable health risk (Lauwerys, 1991).

In practice, this requires regulatory agencies to set permissible levels of human exposure to chemicals in public and occupational settings. Examples include reference doses set by the EPA; threshold limit values (TLVs or time-weighted averages (TWAs)) set by the American Conference of Governmental Industrial Hygienists (ACGIH); and, permissible exposure limits (PEL) set by OSHA. In general, industrial exposures are the average level of exposure for a normal $8 \mathrm{hr}$ workday and a 40-hr work week, to which nearly all workers may be repeatedly exposed, day after day, for a working lifetime, without adverse effects (ACGIH 1994). Similarly, for the public, exposure limits are based on an average level of exposure occurring over many years (20) or a lifetime to which the public could be continuously exposed without causing adverse health effects.

In the establishment of these regulations and guidelines, a body of toxicologic information is required to evaluate what measure and type of risk to health is acceptable. Principally, data from two different sources are used:

- Experimental investigation on animals

- Clinical surveillance of exposed populations.

Using animals, many different types of data can be developed including: 
- Acute Toxicity (studies of $<5$ day exposure). This is usually the first toxicity test performed on a new chemical. The LD50 and other acute toxic effects are usually determined. One or more routes of exposure may be selected: Oral, Eye, Skin Irritation, Skin Absorption, and Inhalation.

- Subacute Toxicity ( 5 to 14-day studies) - These studies are about the tox city of a chemical after repeated administration, and are used as a means for establishing the doses for subchronic studies.

- Subchronic Toxicity (15-day to 6 months studies) - Subchronic studies are used to establish a no observable effect level and to further identify and characterize the specific organ(s) affected by the test compound after repeated administrations. They are usually performed in two species.

- Chronic Toxicity and Carcinogenicity (>6-month studies) - Chronic toxicity tests are performed to assess the cumulative toxicity of chemicals, and often include carcinogenic potential of chemicals.

- Reproductive and Developmental Toxicity - Reproductive toxicology is the study of adverse effects on the male or female reproductive system. Developmental toxicology is the study of adverse effects on the developing organism prior to conception. Several types of animal tests can be used: General fertility and reproductive performance tests.

- Genotoxicity/ Mutagenicity - These studies deal with the ability of chemicals to cause changes in genetic material.

- Metabolism/Pharmacokinetics - These studies explore the underlying mechanism by which chemicals exert their toxic effects on living organisms. Results of these studies can lead to development of predictive tests for determining exposure to a chemical.

Human data are emphasized in developing exposure limits. When it is available, it usually gives only effects observed at either unknown, or extreme (very short-term, very low concentrations or very high concentrations) levels of exposure. Further, there is a large dependence on the use of retrospective epidemiological (statistical) studies based on clinical examinations combined with other measured (e.g., contaminant concentration in the air) and anecdotal data (e.g., number of days a worker was exposed to a chemical and a specific concentration). Finally, unlike animal studies where all conditions are carefully controlled, similar conditions are rarely found for human populations. Because this type of information is seldom available, regulators often depend on animal data for decision-making purposes.

For both human and animal data, it is generally understood that all chemicals are toxic and produce harm, but only within prescribed conditions of exposure. This relationship may be characterized by a dose-response function which is a mathematical relationship describing the proportion of test organisms responding for a given dosage interval, for a given exposure period. For example, the number of fatalities observed in an animal study might increase consistently, as the amount of the chemical introduced into the organism is increased. As a rule, the intensity of the response decreases with reduction in dose, and a biological reaction often reaches zero before the dose becomes equal to zero. Below a certain limiting exposure levels or dose, (i.e., below the threshold) a chemical substance may not elicit a toxic effect (Figure 1). It has long been recognized that acute toxicological responses are associated with thresholds - that is there is some dose below which the probability of an individual responding is zero. The biological bases of thresholds for acute responses is well founded and frequently can be demonstrated based on mechanistic information. The traditional approaches to establishing acceptable levels of exposure to chemical are inherently different between threshold and nonthreshold responses. The existence of threshold for chronic exposures is less well defined, especially in the area of chemical carcinogenesis. It is, of course, impossible to scientifically prove the absence of a threshold. Nevertheless, for identification of "safe" levels of exposure to a substance, the absence or presence of a threshold is important for practical reasons. 


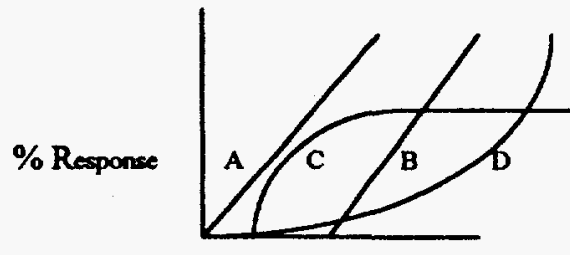

A $=$ No Threshold Response
$B=$ Threshold Response
C = Continuous with Threshold
$D=$ Continuous with NoThreshold

Hypothetical Dose Units

Figure 1: Alternative Dose Response Relationships

Current theory suggests that there is no threshold for chemicals capable of producing mutagenic and carcinogenic responses. That is for genotoxic carcinogens (initiators) the rate of cancer is a continuous response with a decreasing probability until zero exposure is met. Practically speaking, while each exposure is considered to potentially carry some risk, an acceptable risk must be agreed upon for the sake of risk management. EPA's cancer assessment group has used a lifetime risk of $10^{-6}$ as the acceptable limit of risk for the population. This risk suggests that if one million people were exposed to the given agent, one individual would contract cancer who should not have contracted it, or would have contracted it at a later date.

\section{TOXICITY DATA FOR CIS, CGS, and CdTe}

Preliminary animal toxicity data on CIS, CGS, and CdTe have been developed by Chapin et al. (1994) from the National Institute of Environmental Health Sciences located in Research Triangle Park, North Carolina. Presented below is a summary of the biological effects observed in these studies, and a brief guide to their interpretation.

\subsection{Study Design And Methods}

In all cases, the compounds were suspended in $0.5 \%$ hemimethylcellulose and administered to adult male and female Sprague-Dawley rats daily by oral gavage. A 28-day dose-range-finding (DRF) study was conducted for each compound in order to set doses for the main study. This DRF study involved no mating, just dosing to group-housed adult rats. Doses for these DRF studies were $1000,500,250,100$, and $0 \mathrm{mg} / \mathrm{kg} / \mathrm{d}$, due to the lack of any preliminary toxicity data. The endpoints used were body weight, clinical signs, food and water consumption, hematology, clinical chemistries, and selected organ histopathology at sacrifice.

These preliminary data were used by Chapin et al. to set doses for the main study with the aim that the top dose would be expected to reduce body weight gain to some degree. The rationale for this is that if no body weight reduction and no adverse effects were seen, Chapin et al. could only conclude that not enough of the compound was given, and the data from such a study would be of limited use. The lack of toxic effects in the presence of reduced body weight (or reduced weight gain, for a short-term study) is more reassuring, for it indicates that the animals were already being given as much compound as could reasonably tolerate; some degree of reduced body weight or body weight gain increased Chapin et al's. confidence in a negative study, (i.e., a study that finds no toxic effects other than weight reduction).

The design for the main study is adapted from Harris et al. (1992), but extended by a week (Figure 2). The design looks at "systemic" toxicity in male rats: hematology (red and white blood cells), clinical chemistry (enzymes and proteins in the blood, used as circulating markers of tissue damage), histopathology of liver, kidney, spleen (to identify structural changes in those vital organs, which are some of the known target organs for these compounds). Systemic toxicity is evaluated only in males, because the pregnancy status of the females may be altered by exposure to the compound, and since both pregnancy and treatment affect these systemic endpoints, interpretation of systemic toxicity in females is very difficult. In addition, the design evaluates any effects of exposure on: 
- Both the function (breeding) and structure of the male reproductive system. In addition, Chapin et al. evaluated sperm number in the epididymis and testis, sperm motility, and the structure of the testis and epididymis. This is done in Group 1, the males.

- The ability of the compound to affect female fertility (Group 2). In this design, female fertility is separated, from fetal development, and is defined as the ability to become pregnant and initiate fetal development. This includes the ability to ovulate, fertilize the ovum, implant the conceptus, and begin development.

- The ability of the compound to affect fetal development, birth, and the initiation of lactation (in Group 3). This is accomplished by dosing the females during the period of major fetal organogenesis. This has been thought to be the most sensitive period of fetal development, and is a practice accepted widely in teratology. The animals are dosed from gestation days $6-15$, then dosing is stopped, and the dams are allowed to deliver their litters. Fetal number and weight gain are monitored for the first 4 postnatal days. Even though the animals are maintained without dosing for the last third of gestation, parturition, and lactation, Chapin et al. saw chemical-related effects in treated animals in these undosed later periods in previous studies.

\subsection{Results}

\subsubsection{CIS}

Doses for the main study were set at 50,100 , and $250 \mathrm{mg} / \mathrm{kg} / \mathrm{d}$.

Group 1 - Males (Table A1): CIS did not affect food consumption, body weight, or clinical chemistry values in males dosed continuously for 28 days. Liver weight was slightly increased. There were small, not biologically significant, changes in red cell production and monocyte (a type of white cell) numbers. There were no effects on any reproductive endpoints in males.

Group 2 - Continuously Exposed Females (Table A2): CIS reduced female food consumption and weight gain at the top dose, but did not alter either the number of live, or dead, uterine implants (fetuses) in these females, or the number of corpora lutea. This shows that CIS had no effect on ovulation or early fetal development during this time frame.

Group 3 - Gestational Exposure (Table A3): CIS reduced body weight gain during treatment, but not food consumption. There was a significant (25\%) reduction in the number of live pups delivered in the high dose group (250 $\mathrm{mg} / \mathrm{kg}$ ), but these pups each were, on average, heavier than their controls. This indicates that their intrauterine development was not stunted. Normally, when there are fewer pups per litter, each of them is expected to be heavier. If there are fewer pups per litter and each is lighter than controls, the weight change indicates an adverse effect on fetal development, and the reduced pup number indicates an adverse effect on parental fertility.

Collectively, these data show that sufficient CIS was given to reduce body weight gain, both with and without a change in food consumption (groups 2 and 3, respectively). Weight and pup effects, in the absence of changes in food consumption (seen in Group 3), and in the presence of a bulky metal suspension, suggested the possibility thats ome nutritional inadequacies might account for the reduced litter size. A pair-feeding study was conducted to test the possibility that the CIS effect on pup number was due to impaired nutrition primarily (Table A4). This study consisted of a group of untreated, control pregnant females, a group treated with $250 \mathrm{mg} \mathrm{CIS} / \mathrm{kg}$, and a group that received, each day, only as much food as that consumed by the CIS group. If the "CIS effects" were due to deficient nutrition, then the pair-fed group should also have reduced litter size. Surprisingly, Chapin et al. found, that all three groups had the same sized litters; CIS did not reduce the number of pups/litter, nor was pup number reduced in the pair-fed group. This shows not only that there was no adverse effect of reduced food consumption, but also that the CIS "effect" is a relatively small one, since it cannot be repeated consistently. 


\section{SUBCHRONIC TOXICITY SCREEN INCLUDING OBSERVATIONS FOR REPRODUCTIVE AND DEVELOPMENTAL TOXICITY}

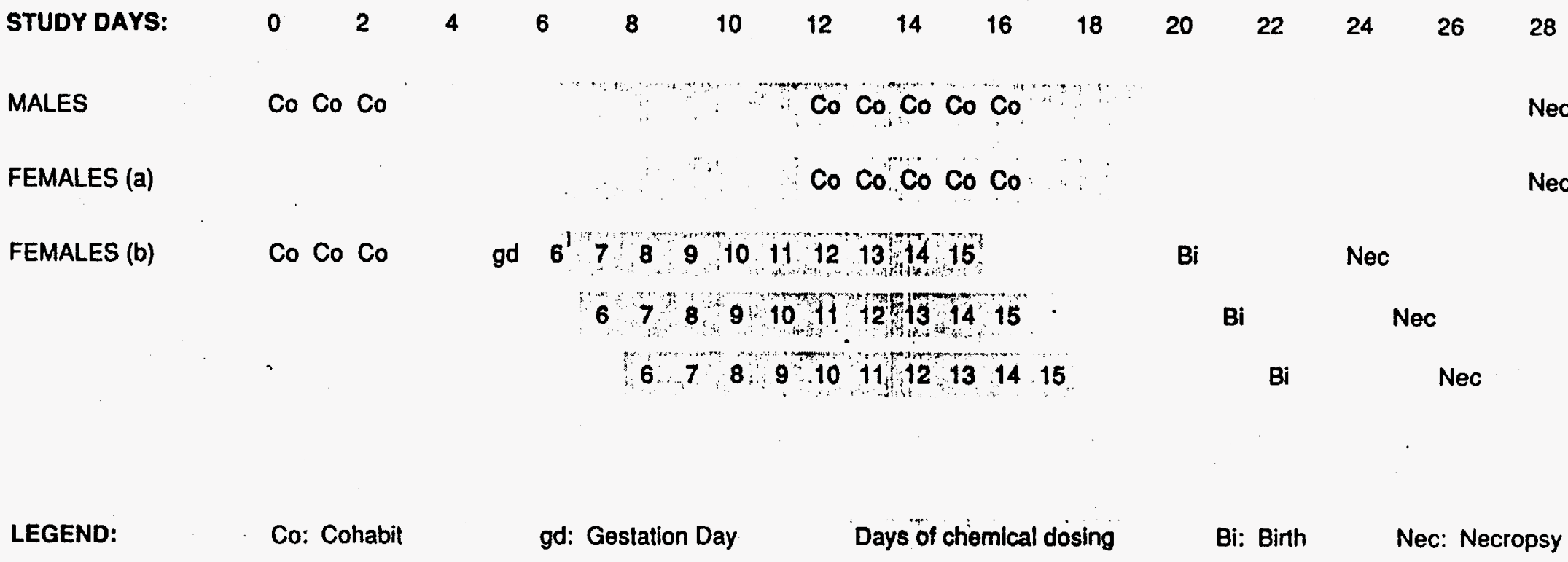

OBSERVATIONS:

MALES

FEMALES (a)

FEMALES (b)

Subchronic toxicity and male fertility ( 3 dose levels plus control, $n=10 /$ group); bw days $3,7,11,15,19,23,28$; modified functional observational battery; gross necropsy; histopathy on liver, kidney, testis; hematology on blood at termination; fertility before and during chemical administration, epididymal sperm motility and total epididymal sperm count.

Subchronic toxicity and female fertility ( 3 dose levels plus control, $n=10$ /group) bw days $0,4,8,12,16,20,24,28$; $\%$ pregnant, number of implants, and number of corpora lutea.

Development toxicity ( 3 dose levels plus control, $n=10$ smear-positive females/group). Confirm mating by vaginal smear or plug during cohabitation; dose females on gd 6 through 15; bw on gd 0,6,10,15, and pnds 1 and 4; number and weight of pups at pnd 1, 4; uterine implantation sites at nec, pnd 4.

Figure 2. Schematic of the design used to evaluate the toxicity of CIS, CGS, and CdTe. Males (Group 1) are cohabited with a group of females (Group 3) for the first three days of the study. The animals are separated at the end of cohabitation. The females are housed until they are dosed from gestation day $6-15$. They are allowed to give birth, and rear their young until postnatal day 4. Meanwhile, the males are dosed from study day (SD) 3 until SD27. These males are mated with another group of females (Group 2) from SD12-SD16. During this time, both sexes are treated with the compound. Food consumption and body weights are measured for all animals. Additional endpoints are: for Group 1, clinical chemistries, hematology, organ weights and pathology, and sperm measures (count and motility); for Group 2, additional endpoints are the number of pregnant females, the number of uterine implants, and the number of corpora lutea. For Group 3, endpoints are the number and weight of pups on postnatal days 0,1 , and 4 , and the number of maternal uterine implantation sites. 
Therefore, based on these data, Chapin et al. conclude that at the doses administered CIS has relatively mild systemic toxicity at doses sufficient to reduce weight gain and overall body weight in treated females. No effect on body weight or clinical chemistry values were seen in males and there was a slight increaser in liver weight and red blod cell production. The fact that the pup number decrease did not occur again when the gestational dosing was repeated in the pair-feeding :tudy suggests that CIS has no consistent reproductive toxicity during this relatively abbreviated exposure period.

\subsubsection{CGS}

Doses for the main study were set at 30,100 , and $250 \mathrm{mg} / \mathrm{kg}$ body wt./day.

Group 1 - Males (Table A5: CGS did not reduce body weight gain or food consumption in males, but liver weights (both absolute and relative to body weight) were increased in the middle and high dose groups at necropsy. There was a dose-related (but probably biologically meaningless) decrease in basophils (a kind of white blood cell) which reached significance at the high dose. Also, there was a dose-related decrease (which reached significance at the top dose, $23 \%$ reduced) in the weight of the cauda epididymis (which stores sperm) and a similar decrease in epididymal sperm count (33\% at the top dose). Testis histopathology was normal, although this might suggest a decrease in sperm production by the testis. Reduced sperm storage could be due to either a reduced output of sperm by the testis or an increased efflux of sperm from the epididymis. The cause of this decline is uncertain since there was no evidence of a reduced output of sperm by the testis, and no reasonable precedent for an increased efflux of sperm from the epididymis.

Group 2 - Continuously-Exposed Females (Table A6): There was a strong dose-related decrease in body weight gain in this group of females. Probably, this was correlated with pregnancy status and food consumption since most of the controls were pregnant, while most of the high-dose animals were not. The high dose animals ate less than the controls, possibly due both to treatment effects and to pregnancy status differences, (i.e., they may have felt bad and eaten less, and non-pregnant animals eat less than pregnant animals). None of the high dose animals had any live implants. They had fewer corpora lutea, as well, indicating that they had ovilated fewer ova. The middle dose group had significantly fewer (by 15\%) live implants than the controls. These data indicate that this level of CGS clearly reduced the ability of females to become pregnant and carry their litter.

Group 3 - Gestational Exposure (Table A7): CGS exposure during fetal organogenesis reduced maternal food consumption by $30 \%$ at the top dose. These animals had significantly reduced body weights during and after treatment. Despite this, there was no significant increase in fetal loss before or after birth, as well as no significant difference in pup weight.

These data identify female fertility in Group 2 as a likely target process. The fertility effects were seen at the same doses that reduced both body weight and survival. Weight reductions similar to those seen in the middle dose group with CGS (which had significantly fewer implants) were not associated with reduced fertility with the other compounds, suggesting that the effects seen here with CGS are probably not simply secondary to body weight effects. Future studies should focus on female fertility and include efforts to repeat these findings.

\subsubsection{CdTe}

Doses for the main study were set at 10,30 , and $100 \mathrm{mg} / \mathrm{kg}$ body wt./day.

Group 1 - Males (Table A 8): There was a dose-related decrease in body weight gain, with the high dose animals losing weight during the study. Food consumption was reduced during the first 11 days of exposure only in the high dose group. There were no effects of CdTe exposure on organ weights, sperm parameters, or fertility. Eosinophils (a white blood cell) were reduced in the high dose group. Serum enzymes indicative of liver damage were increased slightly in the high dose group. Serum albumin levels were increased slightly, probably secondary to dehydration and body weight loss. There were no changes in the structure of the kidneys or livers of these 
animals (known target organs of $\mathrm{Cd}$ toxicity). Additionally, there was no increase in urinary $\mathrm{Cd}$, an index of $\mathrm{Cd}$ exposure, or in protein levels, an index of renal glomerulus toxicity.

Group 2 - Continuously-Exposed Females (Table A9): Animals in the top dose group consumed slightly less food than controls, and gained less thar. half the weight that controls gained during the course of the study. Nonetheless, there was no change in any fertility endpoint (number of live implants, number of dead implants, number of resorptions, number of corpora lutea), indicating that oral CdTe had no effect on these endpoints, and that this difference in body weight gain was not adverse for reproduction during this period.

Group 3 - Gestational Exposure (Table A10): Females dosed during fetal organogenesis with the high dose level consumed less food than controls. Animals in the middle dose group consumed less food from gestational day 8 - 12. There was a dose-related inhibition of weight gain that started at the lowest dose group. Animals in both middle and high dose groups gained significantly less weight during the experiment, and finished lighter than controls. Despite these body weight effects, there were no effects on the pups. There was no increase in fetal loss before or after birth, and no adverse effect on birth weight or weight gain of the pups after birth.

It is known that only $5-8 \%$ of orally administered Cd passes through the lining of the gut to be absorbed by the body (Goyer, 1986). Thus this lack of measurable urinary $\mathrm{Cd}$ is not unexpected. Cd levels are known to rise in the liver and kidney as absorption increases. Then, $\mathrm{Cd}$ starts to appear in the urine. Chapin et al. used the same relatively insensitive biomarker that is used to monitor human $\mathrm{Cd}$ exposure (urinary $\mathrm{Cd}$ ). Therefore, it is possible that there was some renal or hepatic absorption and storage that were not seen, (i.e., that was not reflected in the urinary levels). However, what is more informative is that no change in fertility was seen at this degree of body weight reduction. This increases the likelihood that the changes seen in the CGS study (reduced female fertility) are not simply secondary to the reduced weight gain, but are more likely a toxic effect of CGS per se.

\subsection{Discussion}

These data are an important first step in the determination of the hazards posed by these compounds, but they are a relatively small first step. These studies have a number of serious limitations when it comes to their use in risk assessment (the process of predicting the risk to human health based on animal studies):

- Oral exposure was used in these studies. These compounds were administered by oral gavage into the stomach. This is accepted practice in toxicology, but it does not fully mimic the most likely route of human exposure during manufacturing (which is inhalation). This difference will be critical for several of the compounds: CdTe, since $\mathrm{Cd}$ is so poorly absorbed across the gut epithelium, and is more efficiently absorbed across the pulmonary epithelium, and CIS, since inhaled indium not only may be absorbed, but has been shown to produce lung damage in rats (Blazka et al., 1994). Studies on these three compounds are ongoing at NIEHS, and will document the degree of chemical absorption through the lungs.

- These studies were short-term. These studies are much shorter than most studies used to characterize the toxicity of a compound. The benefit of the current approach is that highly toxic compounds can be identified quickly. The drawback is that if a compound shows no toxicity in these studies, it might still be toxic during longer exposures, or by other routes. This length of study also precludes any conclusions about the possible carcinogenicity of these compounds. Longer studies should be conducted on 1 or $\mathbf{2}$ high-priority compounds.

- Absorption information is needed. This can be remedied relatively easily (by measuring tissue levels of the appropriate elements in treated animals). Tissues have been collected and are awaiting analysis to address this issue. Clearly, if the compound is not absorbed through the gut and is not present in the bloodstream. Then, the issue of appropriate route becomes critical, and another study, using the human route of exposure, must be performed.

- Genetic toxicity data are necessary This can be remedied relatively easily also. Genetic toxicity (damage to the DNA in either regular cells in the body, or to the sperm or eggs) may increase the chances of producing cancer 
or miscarriages/heritable damage in the offspring, respectively. We do not predict that this is likely, based on the structure of these compounds, but it must be addressed at some point.

- Data on lung effects of the compounds are needed. Since the lungs are the probable route of human exposure. This is likely to be most important firr indium (Blazka et al., 1994), but may be relevant for other elements as well.

- Data on reproductive effects of the the compound is insufficient. These studies were for screening purposes only. They did not meet the EPA guidelines for reproductive, fertility effects testing. EPA's guidelines required 1). a larger number of test animals, and 2). that chemical dosing is extended through multible generations. It starts with the parent animals prior to and during the mating, pregnancies and weaning of their F1 offspring, and continues on selected F1 offspring through the production and weaning of the F2 generation. The fact that the study was not long term did not allow for testing of the reproductive function of the second generation, nor for monitoring of longer term reproductive effects on the parents. Although the study was not comprehensive in that exposure did not covering the complete period of gestation, it does represnt a "first cut" assessment of gross teratogenic effects that would be manifested in increased number of dead pups alon gwith gross abnormalities at birth.

- Limited general toxicity data was provided. The next study could expand the clinical chemistry, hematology, and histopathology data, especially the histopathology (more organs could be evaluated).

- Data on lung effects of the compounds are needed. Since the lungs are the probable route of human exposure. This is likely to be most important for indium (Blazka et al., 1994), but may be relevant for other elements as well.

- The purpose of the study was to serve as a first pass screening for a variety of different effects but focused on reproductive effects.

- The study was meant as a screening for reproductive and fertility effects. This study does not meet the Office of Prevention, Pesticides and Toxic Substances guidelines for such testing as follows:

- Limitations include the limited number of animals used, and limited study length (the study did not follow animals down to the offspring of the second generation).

- The substance should be administrated to parental animals prior to a and during the mating, during the resultant pregnancies and through the weaning of their offspring. Then it must be administered to selected offspring during their growth into adulthood, mating and production of a second (F2) generation until the F2 generation is weaned.

- The study did not monitor the reproductive function of the second generation nor evaluate longer term effects on the first generation.

- The purpose of the testing was to determne reproductive effects, not to evaluate other systemic toxicities. One can develop specific NOELs and LOELs for reproductive effects - but this is only acceptable if reproductive effects was the most sensitive endpoint. It would be inappropriate to extrapolate these results to an overall NOEL or LOEL or RfD even if this is the only data that is available. Often the health professional is presented with such a situation. That is the availability of llimited data with which to make health related recommendations.

These studies give us some idea of the processes that are likely to be most sensitive if the compounds do get into the bloodstream. This design is able to identify chemicals that do cause significant toxicity with longer exposures (Harris et al., 1992). These data suggest that CIS and CdTe, are not significantly more toxic than the individual elements during this limited time frame, and based on information about the toxicity of the individual elements. The female reproductive toxicity of CGS requires more investigation in order to compare the effects against the toxicity of the individual elements. More work should be done with CGS if it appears to be commercially viable, and if it is likely to move into production. 


\section{DERIVED REFERENCE DOSES FOR CIS, CGS and CdTe}

As discussed in Section 2, exposure limits are derived from information collected in toxicological studies. Both the lowest-observed-adverse-effect level (LOAEL) and the no-observed-adverse-effect level (NOAEL) are obtained, from chronic toxicity studies in laboratory animals. The NOAEL is the highest dose administered which does not produce toxic effects. The number obtained for the NOAEL will depend on how closely the LOAEL and NOAEL dosages are spaced, and the number of animals examined. The objective is to extrapolate from a "safe" dosage in laboratory animals to a "safe" dosage for humans. Most often, the extrapolation made is from highdosage studies in laboratory animals to low doses in humans.

The standard approach for establishing "acceptable" levels of exposure for chemicals is to reduce the NOAEL by a safety or uncertainty factor that considers both intraspecies and interspecies differences. EPA has developed a standardized method for deriving regulatory values for threshold-based responses. This reference dose (RID) incorporates a standardized number as an "uncertainty factor" and includes "modifying factors" which provide additional uncertainty factors that allows for professional judgment in the estimation of allowable levels. This modifying factor is a value greater than zero but less than 10 , with a default value of 1 . An RfD value is obtained by dividing the NOAEL determined in animal studies by the product of the uncertainty factors and the modifying factors. Standard uncertainty factors and modifying factors are shown in Table B1. These uncertainty factors include factors of variability of species, particularly in the extrapolation from animal to human. Often, a safety factor of 10 is applied when chronic exposure data in humans are used to take into account additional variability between humans. This information is frequently not available for the chemical in question. Therefore, chronic exposure data in laboratory animals must be used. A safety factor of 100 is used when extrapolating from animal to humans. This is derived by using the uncertainty factor of $\mathbf{1 0}$ for differences in the human population, and an additional factor of 10 for differences between species. Often, a safety factor of 1000 is used when reliable chronic exposure data are not available. This is derived by using the uncertainty factor of 10 for differences in the human population, an additional factor of 10 for differences between species, and another additional uncertainty factor of 10 for when reliable chronic results are not available. This is derived by adding an additional factor of 10 when the LOAEL is used to derive the RfD rather than the NOEL. A safety factor of 10,000 is used when extrapolating a NOEL from a LOEL. This number represents the uncertainty when extrapolating a NOAEL from a LOAEL.

Reference concentrations $(\mathrm{RfC})$ that are used for estimations of inhalation exposures are equivalent concepts. Oral RfD and inhalation RfCs are used on long-term toxic effects other than carcinogenicity. Other models are used if carcinogenicity is considered to be an endpoint.

In this study, tentative oral RID's were estimated as a first step in establishing the range of population risk that might be associated with exposure to CIS, CGS, and CdTe. These were based on recent results from a comprehensive, but short-term screening study undertaken by Chapin et al. (1994) to assess the systemic, reproductive and developmental toxicity of these compounds.

An implied exposure threshold, combined with a methodology developed by the EPA to establish RID's for non-carcinogenic substances, was used to extrapolate results from the Chapin et al. study series to the general human population. The general approach to develop the RID's outlined in Table Bl takes into account the major uncertainties that are associated with extrapolation from subchronic studies in animals to lifetime risk in sensitive sub-groups of the human population. Four major areas of uncertainty were related immediately to provisional estimates from the Chapin et al. data. These are designated as uncertainty factors (Uf) and in the aggregate they span four orders of magnitude between the evidence in the subchronic animal study to sensitive human sub-groups.

Under optimal circumstances, the estimates could be based on the maximum exposure, yielding a NOAEL. The NOAEL, however, is sensitive to the number of animals employed at each dose, given the screening nature of the Chapin et al. studies, the minimal numbers at each dose, and the loss of animals through death. Thus, the LOAEL was employed for estimation purposes. A base modifying factor (MF) of 2 was used to further compensate for the study limitations (see Table B2). This was to account partially for the differential between a 28 
vs. 90 day sub-chronic study, and the inclusion of only a single sex in evaluating systemic toxicity. This may not be conservative enough to fully compensate for the limitations inherent in a very short-term study protocol.

The sbligatory use of the LOAEL and an MF of at least 2 represents the penalty associated with using short-term studies. As noted, the adjustment may be only marginally conservative, and a more stringent MF may be required. The importance of this is not trivial as demonstrated in cadmium sulfide inhalation studies. Shortterm exposure showed a high tolerance for the agent, although the route of administration was different. In contrast, the chronic inhalation studies demonstrated a severe delayed response leading to death. The quality of the data from the chronic study were diminished from late occurring toxic effects since the chronic study had been designed to evaluate carcinogenesis.

An example calculation following the EPA paradigm is shown in Table Bl for CdTe. The product of the four standard uncertainty factors was 10,000. Since the data represented sub-chronic exposure, the use of the LOAEL, and extrapolation to sensitive population subgroups. This also holds for all other compounds (CIS and CGS). A professionally based modifying factor of 2 was included to account for single sex systemic toxicity. The resultant RID was $0.005 \mathrm{mg} / \mathrm{kg} /$ day.

EPA has set an RfD of $5 \mathrm{E}^{-4} \mathrm{mg} / \mathrm{kg} / \mathrm{day}$ (water) for Cd (IRIS 1994). An equivalent RfD for Cd in food is $0.001 \mathrm{mg} \mathrm{Cd} / \mathrm{kg} /$ day. This was based on a estimated NOAEL of $0.005 \mathrm{mg} \mathrm{Cd} / \mathrm{Kg} /$ day for $\mathrm{Cd}$ in drinking water and incorporated an uncertainty factor of 10 and a modifying factor of 1 was incorporated. Although $\mathrm{Cd}$ is considered a lung carcinogen and it is also known to cause both long-term kidney and bone effects. In developing its RfD, EPA used a NOAEL value that would not demonstrate kidney damage. There is a high confidence in this RfD due to the abundance of toxicity data for both humans and animals. The data permitted calculation of pharmacokinetic parameters of $\mathrm{Cd}$ absorption, distribution, metabolism, and elimination. The RfD was based on the highest level of $C d$ in the human renal cortex which was not associated with significant proteinuria. There are differences in absorption depending on the source of $\mathrm{Cd}$ (food vs. drinking water). These differences were used in the toxicokinetic model to determine $\mathrm{RfD}$.

There is limited toxicity information for CdTe in comparison. No human data are available. The data that are available are from animal studies, represent sub-chronic exposure, and uses LOAEL rather than NOAEL values. Therefore, an uncertainty factor of 10,000 is used and a modifying factor of 2 are used since only single sex toxicity information is available. These assumptions resulted in an $\mathrm{RDD}$ of $0.005 \mathrm{mg} / \mathrm{kg} /$ day, which is an order of magnitude higher than for $\mathrm{Cd}$. If a MF of 10 is used then the RfD would also be $0.001 \mathrm{mg} / \mathrm{kg} / \mathrm{day}$. The implication, is that CdTe is not as toxic as Cd compounds as a whole but if different assumptions are used, it may be as toxic as $\mathrm{Cd}$. The model was developed based on the existing limited toxicity. The endpoint was reproductive and developmental effects. The short nature of the study is not suitable for determining long-term kidney effects. The modifying factors and uncertainty factors may change as more toxicity evidence becomes available. Although the RID's are comparable, the confidence around the RfD is low, because:

\section{- A NOAEL was not used}

- The information reflected information from only one study

- The data did not take into account any pharmacokinetic parameters (e.g. absorption, distribution, metabolism and elimination).

EPA set a $\mathrm{RfD}$ of $5 E^{-3} \mathrm{mg} / \mathrm{kg} /$ day. and a NOAEL level of $0.015 \mathrm{mg} / \mathrm{kg} /$ day for Se. An uncertainty factor of 3 was used to account for sensitive individuals. A modifying factor of 1 (default value) was used. This value will prevent the development of clinical selenosis (e.g., hair or nail loss). The confidence in this study was high based on the many animal studies and epidemiology studies, although there are no other reliable biochemical or clinical indicators of Se toxicity except for clinical signs of selenosis. 
The estimated RID for CIS is $0.0083 \mathrm{mg} / \mathrm{kg} /$ day in comparison. The uncertainty factors were similar to that used for CdTe, however, a modifying factor of 3 was selected to account for systemic toxicity in only one sex, as well as to include factors such as deficit number of live pups in the main study, and non-statistically significant, but borderline, deficit in male fertility.

Table B2 summarizes the target toxicological end-points thought relevant from the Chapin et al. studies, as well as the corresponding NOAEL and LOAEL. As noted, there was a suggestion of borderline deficits in male fertility for CIS exposure. At top exposure, 6 of 9 males were fertile, in contrast to 9 of 9 in controls. A $>30$ percent reduction was biologically significant, while the specific contrast was almost statistically significant. Thus more animals would have been helpful in confirming or rejecting the notion of deficits in male fertility. Clear deficits in live implants were noted by Chapin et al. at a CIS level of $250 \mathrm{mgs}$. There was an average of 6.2 implants/female at this dose, vs. 11.3/female in controls. There were 9 pregnant rats among controls but only 6 at 250 mgs (a possible result of decreased male fertility already noted at this exposure. The contrast between controls and exposed was of only borderline statistical significance as a result of the diminished sample size. Again, this emphasizes the importance of sufficient study size in future evaluations.

Summary oral RfD's are shown for each compound in Table B3, with the corresponding daily intake based on a standard $70 \mathrm{~kg}$ man. These agree with Chapins's wider findings that CIS and CdTe were clearly less toxic than CGS. Projected elemental RfD's were made for each substance using the compound specific RID's, and summarized in Table B4. EPA gives an actual oral RfD for Se of $5 \times 10^{-3} \mathrm{mg} / \mathrm{kg} /$ day (U.S. EPA 1994). CIS is as toxic as expected from EPA data. CGS is significantly more toxic. Again, this may be just the effect of modifying factors included in the $\mathrm{RPD}$ estimates. The benchmark $\mathrm{RfD}$ for ingested $\mathrm{Cd}$ is given as $1 \times 10^{-3}$ for ingestion. Comparison with Table B4 suggests that CdTe would be slightly less toxic than expected even with significant discounting as a result of the limitations surrounding the data. However if more conservative assuptions are used, the expected toxicity of CdTe would be equivalent to $\mathrm{Cd}$.

\section{IMPLICATIONS OF THESE FINDINGS TO THE PHOTOVOLTAICS INDUSTRY}

When little information is available on a compound, such as CdTe, the parent compound is regarded as a surrogate and toxicity is inferred from those data. Of the parent compounds, $\mathrm{Cd}$ is considered more toxic and is currently regulated by OSHA under 29 CFR $1910.1027 \mathrm{Cd}$. It is considered a lung carcinogen and is known to cause both long-term kidney and bone effects. The acute health effects from inhalation of Cd include pneumonitis, pulmonary edema, and death. Regardless of the route of absorption, approximately one half to one third of the body burden of $\mathrm{Cd}$ is found in the kidneys, with the highest concentration in the renal cortex. Even if it is stored in other compartments, evidence indicates that $\mathrm{Cd}$ stored in one body compartment can be transported to the kidney where it causes renal damage. Conversations with OSHA indicates that they consider all Cd compounds to be toxic, and CdTe was specifically included in the standard. In 1992, OSHA lowered its 8-hr permissible exposure level (PEL) for Cd compounds to $5 \mathrm{mg} / \mathrm{m}^{3}$. During the rule-making, the Dry Color Manufacturers Association (DCMA) submitted studies to the docket, to support the position that Cd in pigments is less bioavailable than the $\mathrm{Cd}$ in other compounds. They stated that in contrast to the sulfide, cadmium oxide is highly soluble in dilute acids, which explains, in DCMA's view, the equivalent lung toxicity of cadmium oxide and other water-soluble Cd compounds. OSHA considered these data inadequate to develop public policy decisions that would allow some workers to be exposed to higher amounts of $\mathrm{Cd}$ than other workers based upon type of compound alone. In the absence of data that indicate only relatively insoluble forms of cadmium sulfide will be present OSHA cannot separate one Cd compound from others for regulatory purposes. OSHA believes that they must err on the side of worker-health and believes that mixtures of relatively more and less soluble forms will be present at one time or another in the workplace.

Based on this general guidance, all facilities working with any of these compounds researchers should continue to control exposures. This includes monitoring, engineering controls, the use of personal protective equipment, and good work practices. Additionally, although no exposure limits exist for any of these materials, 
such limits exist for some of their precursor compounds. In the absence of specific regulatory guidance, these should be followed.

\section{REFERENCES}

American Conference of Governmental Industrial Hygienists, Inc., (1994) 1994-1995 Threshold Limit Values for Chemical Substances and Physical Agents and Biological Exposure Indices, Cincinnati, Ohio.

Blazka, M.E., Dixon, D., Haskins, E., and Rosenthal, G.J. (1994). Pulmonary toxicity to intratracheally administered indium trichloride in Fischer 344 rats. Fundam. Appl. Toxicol. Vol. 22, pp. 231-239.

Chapin, R.E., M.W. Harris, J.D. Allen, E.A. Haskins, S.M. Ward, R. E. Wilson, B.J. Davis, B. J. Collins, and A.C. Lockhart (1994). The Systemic And Reproductive Toxicities Of Copper Indium Diselenide, Copper Gallium Diselenide, And Cadmium Telluride In Rats. In Press.

Harris, M.W., R.E. Chapin, A.C. Lockhart, and M.P. Jokinen (1992). Assessment of a short-term reproductive and developmental toxicity screen. Fundam. Appl. Toxicol. Vol. 19:, pp. 186-196.

Klaassen, C.D. and Eaton, D.L., (1991). "Chapter 2: Principles of Toxicology," Casarett and Doull's Toxicology, The Basic Science of Poison, Amdur, M.O., Doull, J., and Klaassen, C.D. (eds.). 4th Edition, Pergammon Press Inc., Elmsford, NY.

Laurwerys, R.R. (1991) "Chapter 29: Occupational Toxicology," Casarett and Doull's Toxicology, The Basic Science of Poison, Amdur, M.O., Doull, J., and Klaassen, C.D. (eds.). 4th Edition, Pergammon Press Inc., Elmsford, NY.

Pfitzer, E.A. (1976) "General Concepts and Definitions for Dose-Response and Dose-Effect Relationships of Toxic Metals," In: Effects and Dose-Response Relationships of Toxic Metals. Nordberg, G. (ed.), Elsevier Scientific Publishing Company.

WHO (1978) Environmental Health Criteria 6. Principles and Methods for Evaluating the Toxicity of Chemicals, Part 1, World Health Organization, Geneva.

U.S. Environmental Protection Agency (1994). IRIS, Integrated Risk Information System. 
APPENDIX A. SUMMARY OF TOXICITY TESTING RESULTS FOR CIS, CGS, AND CdTe 
Table A.1

GROUP 1

Male Sprague Dawley Rats

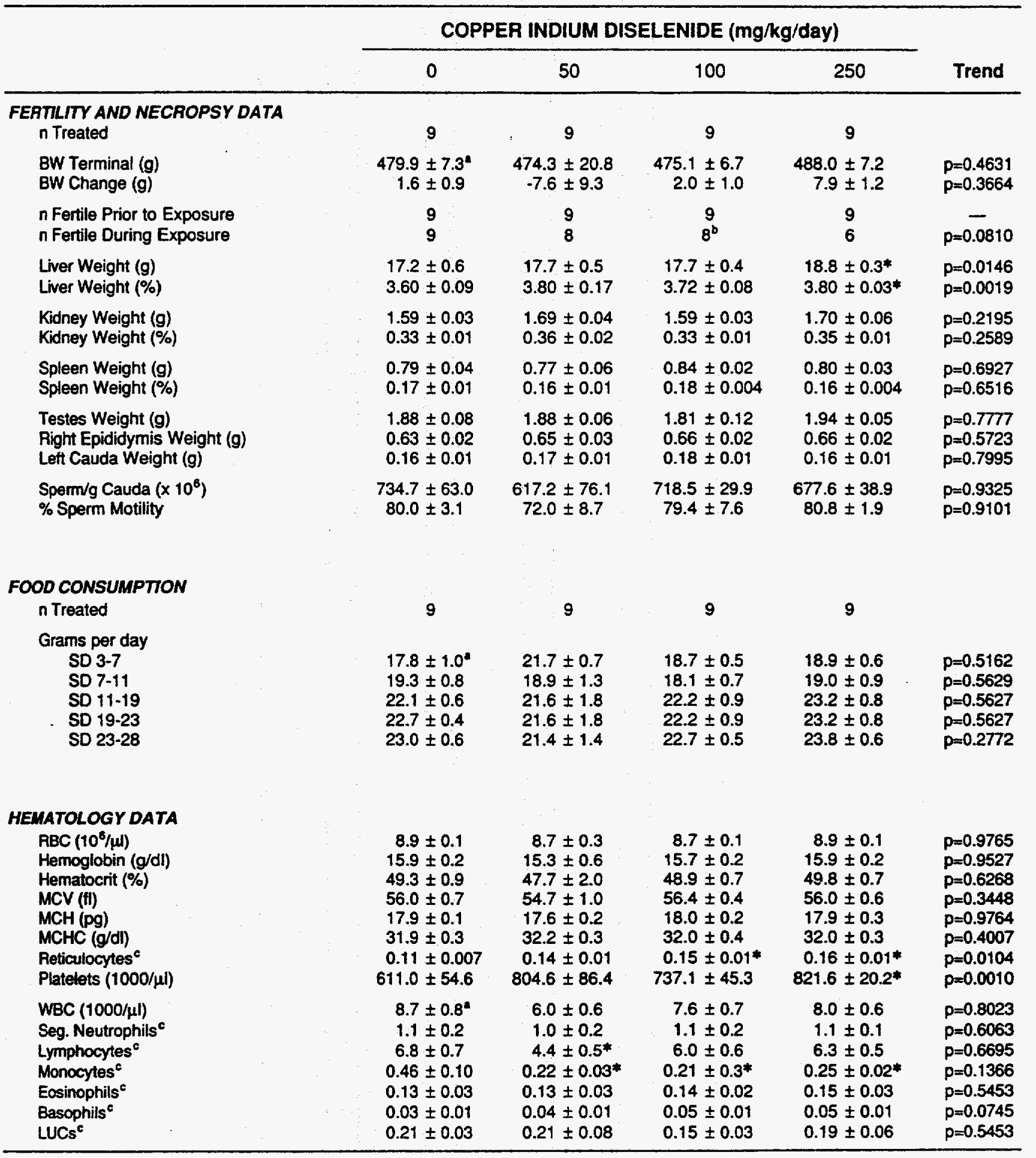

- Maen \pm SEM

'Only eight females available

'Exprossed as absolute values

"pe0.05 compared to controls 
Table A.2

GROUP 2

Continuous Exposure

Female Sprague Dawley Rats

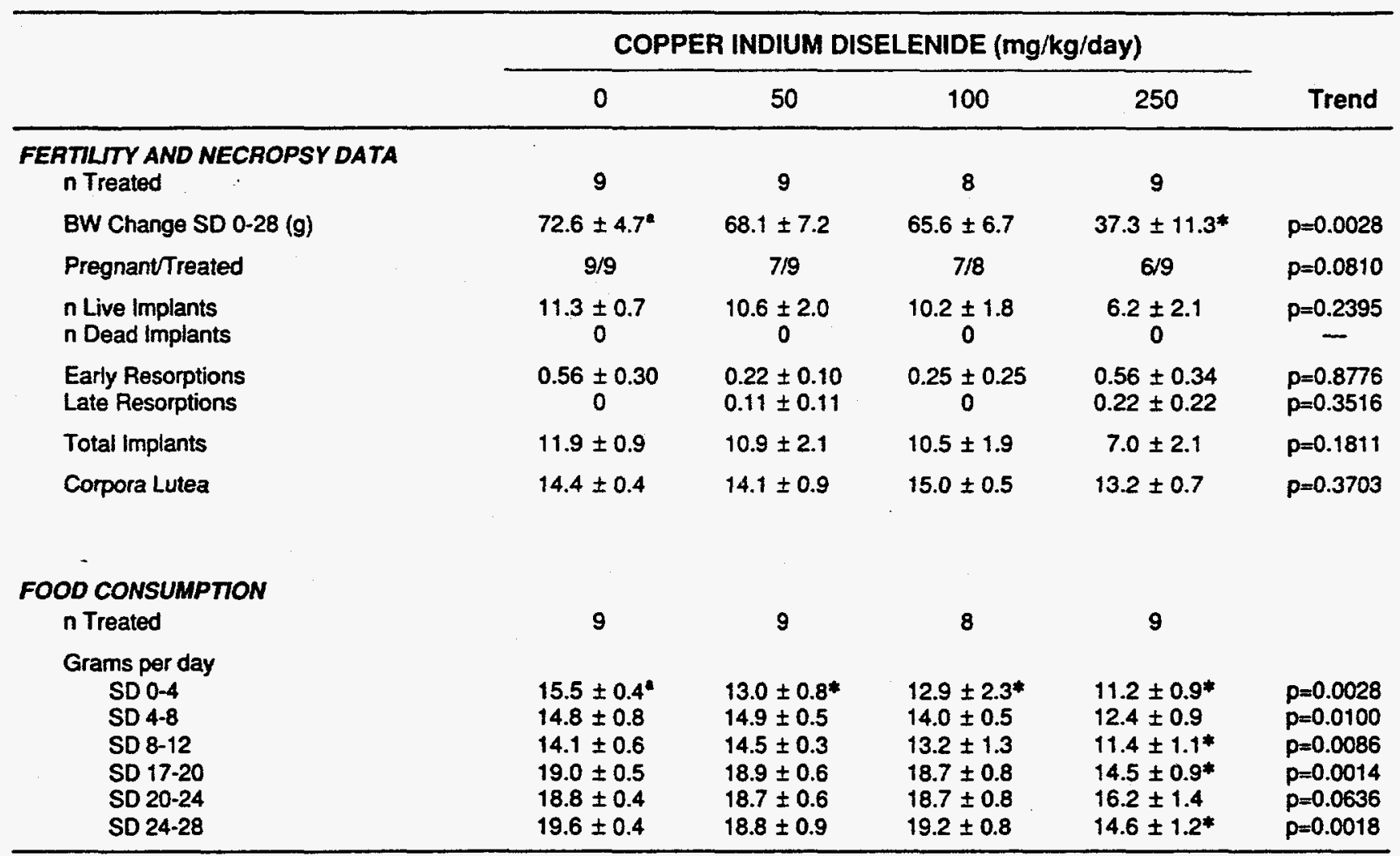

-Mean 4 SEM

*p<0.05 compared to controts 
Table A.3

\section{GROUP 3}

\section{Gestational Exposure}

Female Sprague Dawley Rats

\begin{tabular}{|c|c|c|c|c|c|}
\hline & \multicolumn{4}{|c|}{ COPPER INDIUM DISELENIDE (mg/kg/day) } & \multirow[b]{2}{*}{ Trend } \\
\hline & 0 & 50 & 100 & 250 & \\
\hline \multicolumn{6}{|c|}{$\begin{array}{l}\text { FERTILTTY AND NECROPSY DATA } \\
\text { Females }\end{array}$} \\
\hline Pregnant/Treated & $10 / 10$ & $10 / 10$ & $8 / 10$ & $9 / 10$ & \\
\hline $\begin{array}{c}\text { BW Change (g) } \\
\text { GD 6-15 } \\
\text { GD } 0-15\end{array}$ & $\begin{array}{l}46.4 \pm 1.7^{a} \\
72.1 \pm 2.2\end{array}$ & $\begin{array}{l}53.2 \pm 10.1 \\
68.9 \pm 1.8\end{array}$ & $\begin{array}{l}39.0 \pm 3.0^{*} \\
64.2 \pm 4.0\end{array}$ & $\begin{array}{l}39.1 \pm 1.8^{*} \\
66.8 \pm 2.4\end{array}$ & $\begin{array}{l}p=0.0059 \\
p=0.0651\end{array}$ \\
\hline $\begin{array}{l}\text { BW PND } 1(g) \\
\text { BW PND } 4(g)\end{array}$ & $\begin{array}{l}295.2 \pm 5.5 \\
291.5 \pm 5.7\end{array}$ & $\begin{array}{l}292.1 \pm 3.5 \\
291.9 \pm 2.5\end{array}$ & $\begin{array}{l}289.7 \pm 5.1 \\
286.1 \pm 6.2\end{array}$ & $\begin{array}{l}295.6 \pm 4.3 \\
298.7 \pm 4.3\end{array}$ & $\begin{array}{l}p=0.7551 \\
p=0.6545\end{array}$ \\
\hline \multicolumn{6}{|l|}{$\begin{array}{l}\text { Neonates } \\
\text { PND } 0\end{array}$} \\
\hline $\begin{array}{l}\text { n Live } \\
\text { n Dead }\end{array}$ & $\begin{array}{c}14.8 \pm 0.7 \\
0\end{array}$ & $\begin{array}{r}12.7 \pm 0.9 \\
0.3 \pm 0.3\end{array}$ & $\begin{array}{c}12.9 \pm 0.9 \\
0\end{array}$ & $\begin{array}{c}11.2 \pm 1.1^{*} \\
0.2 \pm 0.2\end{array}$ & $\begin{array}{l}p=0.0031 \\
p=0.3617\end{array}$ \\
\hline $\begin{array}{l}\text { PND } 1 \\
\text { n Live } \\
\text { n Dead }\end{array}$ & $\begin{array}{c}14.8 \pm 0.7 \\
0\end{array}$ & $\begin{array}{c}12.7 \pm 0.9 \\
0\end{array}$ & $\begin{array}{c}12.9 \pm 0.9 \\
0\end{array}$ & $11.2 \pm 1.1^{\star}$ & $\begin{array}{c}p=0.0031 \\
-\end{array}$ \\
\hline $\begin{array}{l}\text { PND } 4 \\
\text { n Live } \\
\text { n Dead }\end{array}$ & $\begin{array}{r}14.7 \pm 0.7 \\
0.1 \pm 0.1\end{array}$ & $\begin{array}{r}12.6 \pm 0.9 \\
0.1 \pm 0.1\end{array}$ & $\begin{array}{c}12.9 \pm 0.9 \\
0\end{array}$ & $\underset{0}{11.1 \pm 1.0^{*}}$ & $\begin{array}{l}p=0.0042 \\
p=1.0000\end{array}$ \\
\hline $\begin{array}{l}\text { Mean Body Weight } \\
\text { PND } 1 \\
\text { PND } 4\end{array}$ & $\begin{array}{l}6.6 \pm 0.1 \\
8.9 \pm 0.3\end{array}$ & $\begin{array}{r}6.9 \pm 0.2 \\
10.3 \pm 0.5\end{array}$ & $\begin{array}{l}7.0 \pm 0.1 * \\
9.7 \pm 0.4\end{array}$ & $\begin{array}{c}7.3 \pm 0.2^{*} \\
10.2 \pm 0.5\end{array}$ & $\begin{array}{l}p=0.0020 \\
p=0.0651\end{array}$ \\
\hline n Implantation Sites & $15.4 \pm 0.7$ & $14.4 \pm 0.9$ & $14.0 \pm 1.0$ & $13.4 \pm 1.1$ & $p=0.0941$ \\
\hline \multicolumn{6}{|l|}{ FOOD CONSUMPTION } \\
\hline \multicolumn{6}{|l|}{ Grams per day } \\
\hline $\begin{array}{l}\text { GD } 6-8 \\
\text { GD } 8-10 \\
\text { GD } 10-12 \\
\text { GD } 12-14\end{array}$ & $\begin{array}{l}20.1 \pm 1.3^{8} \\
19.5 \pm 0.7 \\
22.9 \pm 0.6 \\
22.0 \pm 0.6\end{array}$ & $\begin{array}{l}20.1 \pm 0.9 \\
19.8 \pm 0.7 \\
20.7 \pm 0.7 \\
21.8 \pm 0.7\end{array}$ & $\begin{array}{l}20.9 \pm 1.2 \\
19.4 \pm 1.2 \\
21.7 \pm 0.9 \\
21.8 \pm 1.5\end{array}$ & $\begin{array}{l}17.9 \pm 0.9 \\
19.3 \pm 1.1 \\
20.8 \pm 0.5 \\
22.6 \pm 0.6\end{array}$ & $\begin{array}{l}p=0.2720 \\
p=0.9244 \\
p=0.0980 \\
p=0.3288\end{array}$ \\
\hline
\end{tabular}

-Mean \pm SEM

"peo.05 compered to controls 
Table A.4

\section{PAIR FEEDING STUDY}

\section{Female Sprague Dawley Rats}

\begin{tabular}{|c|c|c|c|c|}
\hline & \multicolumn{3}{|c|}{ COPPER INDIUM DISELENIDE (mg/kg/day) } & \multirow[b]{2}{*}{ Trend } \\
\hline & $\begin{array}{c}0 \\
A d L i b\end{array}$ & $\begin{array}{c}250 \\
A d L i b\end{array}$ & $\begin{array}{c}0 \\
\text { Restricted }\end{array}$ & \\
\hline $\begin{array}{l}\text { FERTILITY AND NECROPSY } \\
\text { Females } \\
\text { n Treated } \\
\text { n Pregnant }\end{array}$ & $\begin{array}{l}11 \\
11\end{array}$ & $\begin{array}{l}12 \\
10\end{array}$ & $\begin{array}{l}12 \\
10\end{array}$ & \\
\hline $\begin{array}{c}\text { BW Change (g) } \\
\text { GD 6-15 } \\
\text { GD 15-21 }\end{array}$ & $\begin{array}{l}51.1 \pm 1.5^{2} \\
86.7 \pm 2.6\end{array}$ & $\begin{array}{l}36.2 \pm 3.4^{*} \\
86.3 \pm 3.5\end{array}$ & $\begin{array}{r}22.5 \pm 3.1^{*} \\
100.1 \pm 7.7^{*}\end{array}$ & $\begin{array}{l}p=0.00008 \\
p=0.0085\end{array}$ \\
\hline $\begin{array}{l}\text { BW PND } 1(g) \\
\text { BW PND } 4 \text { (g) }\end{array}$ & $\begin{array}{l}266.6 \pm 3.1 \\
272.3 \pm 1.8\end{array}$ & $\begin{array}{l}258.1 \pm 5.2 \\
267.7 \pm 4.7\end{array}$ & $\begin{array}{l}257.7 \pm 3.4 \\
269.7 \pm 3.3\end{array}$ & $\begin{array}{c}p=0.0208 \\
N S\end{array}$ \\
\hline $\begin{array}{l}\text { Neonates } \\
\text { PND 0 } \\
\text { n Live } \\
\text { n Dead }\end{array}$ & $\begin{array}{r}12.5 \pm 0.6 \\
0.2 \pm 0.1\end{array}$ & $\begin{array}{r}11.8 \pm 0.7 \\
0.1 \pm 0.1\end{array}$ & $\begin{array}{c}11.3 \pm 1.2 \\
0\end{array}$ & $\begin{array}{l}\text { NS } \\
\text { NS }\end{array}$ \\
\hline $\begin{array}{l}\text { PND } 1 \\
\text { n Live } \\
\text { n Dead }\end{array}$ & $\begin{array}{r}12.6 \pm 0.6 \\
0.1 \pm 0.1\end{array}$ & $\begin{array}{r}11.6 \pm 0.6 \\
0.2 \pm 0.1\end{array}$ & $\begin{array}{r}11.2 \pm 1.1 \\
0.1 \pm 0.1\end{array}$ & $\begin{array}{c}\text { NS } \\
p=0.0313\end{array}$ \\
\hline $\begin{array}{l}\text { PND } 4 \\
\text { n Live } \\
\text { n Dead }\end{array}$ & $\begin{array}{r}12.2 \pm 0.6 \\
0.1 \pm 0.1\end{array}$ & $\begin{array}{c}11.6 \pm 0.6 \\
0\end{array}$ & $\begin{array}{c}11.4 \pm 1.2 \\
0\end{array}$ & $\begin{array}{l}\text { NS } \\
\text { NS }\end{array}$ \\
\hline $\begin{array}{l}\text { Mean Body Weight (g } \\
\text { PND } 1 \\
\text { PND } 4\end{array}$ & $\begin{array}{r}7.2 \pm 0.2 \\
10.6 \pm 0.6\end{array}$ & $\begin{array}{l}7.0 \pm 0.1 \\
9.6 \pm 0.3\end{array}$ & $\begin{array}{r}7.5 \pm 0.2 \\
10.3 \pm 0.3\end{array}$ & $\begin{array}{l}p=0.0170 \\
P=0.0175\end{array}$ \\
\hline n Implantation Sites & $13.8 \pm 0.5$ & $12.8 \pm 0.5$ & $12.2 \pm 1.0$ & $p=0.0315$ \\
\hline
\end{tabular}

-Moan × SEM

* $p<0.01$ compered to controls (ad lib) 
Table A.5

GROUP 1

Male Sprague Dawley Rats

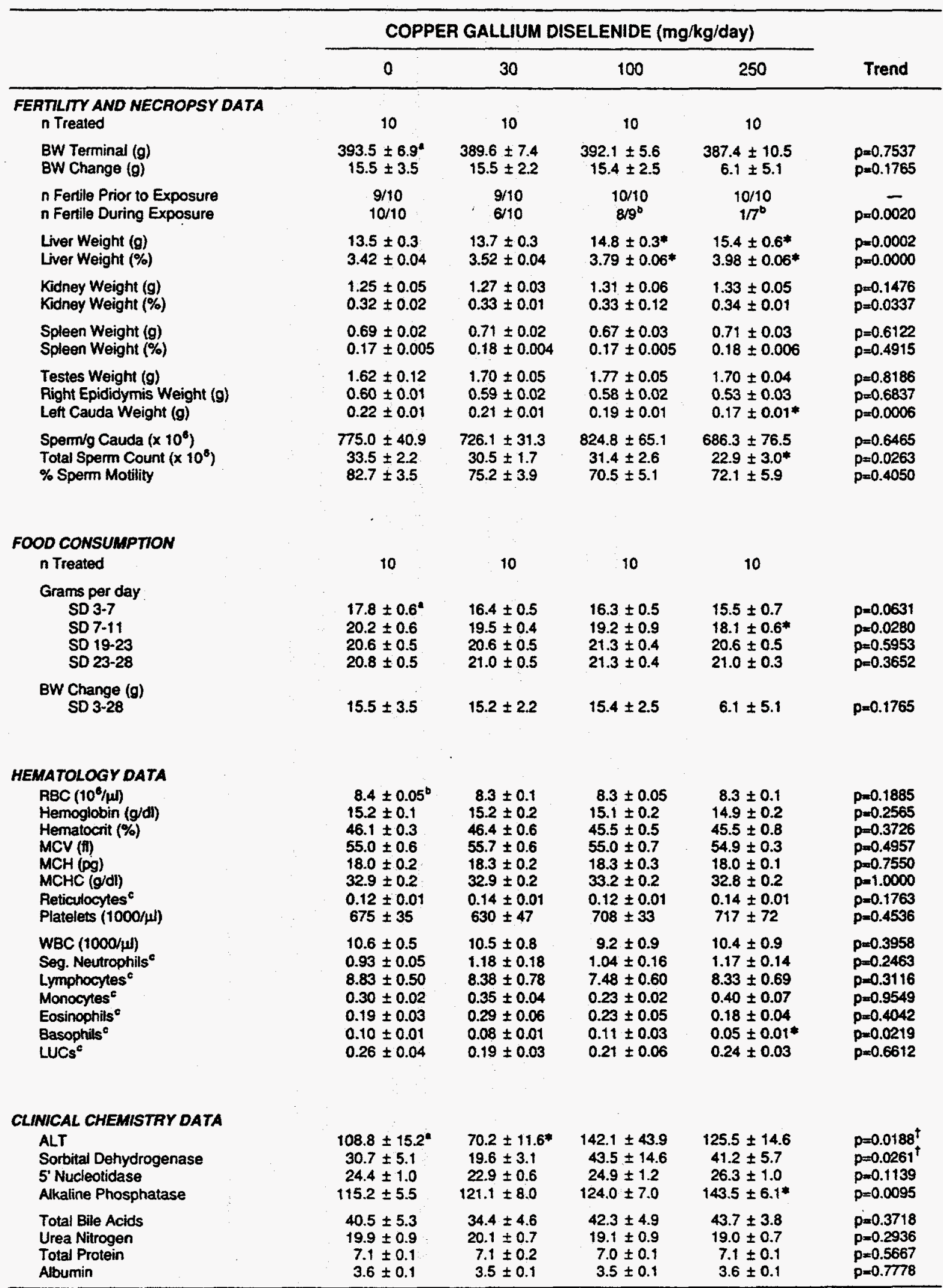

"Maan \& SEM 
Table A.6

\section{GROUP 2}

\section{Continuous Exposure}

Female Sprague Dawley Rats

\begin{tabular}{|c|c|c|c|c|c|}
\hline & \multicolumn{4}{|c|}{ COPPEA GALLIUM DISELENIDE (mg/kg/day) } & \multirow[b]{2}{*}{ Trend } \\
\hline & 0 & 30 & 100 & 250 & \\
\hline $\begin{array}{l}\text { FEATILITY ANO NECROPSY DATA } \\
\text { n Treated }\end{array}$ & 10 & 10 & 10 & 10 & \\
\hline BW Change SD 0-28 (g) & $73.3 \pm 3.8^{\star}$ & $61.3 \pm 7.2$ & $53.2 \pm 3.4^{*}$ & $8.9 \pm 9.7 *$ & $p=0.00002$ \\
\hline PregnantTreated & $10 / 10$ & $6 / 10$ & $8 / 9^{6}$ & $1 / 7^{6}$ & $p=0.0020$ \\
\hline n Live Implants & $13.2 \pm 0.6$ & $13.0 \pm 0.9$ & $11.2 \pm 0.5^{*}$ & 0 & $p=0.0095$ \\
\hline $\begin{array}{l}\text { Earty Resomptions } \\
\text { Late Resorptions }\end{array}$ & $\begin{array}{c}0.4 \pm 0.2 \\
0\end{array}$ & $2.0 \pm 0.9^{*}$ & $\begin{array}{c}0.1 \pm 0.1 \\
0\end{array}$ & $\begin{array}{l}4 \\
0\end{array}$ & $p=0.0106^{\dagger}$ \\
\hline $\begin{array}{l}\text { Total Implants } \\
\text { Corpora Lutea }\end{array}$ & $\begin{array}{l}13.6 \pm 0.6 \\
15.6 \pm 0.9\end{array}$ & $\begin{array}{l}15.0 \pm 1.0 \\
15.5 \pm 1.3\end{array}$ & $\begin{array}{l}11.4 \pm 0.6^{*} \\
14.7 \pm 0.4\end{array}$ & $\stackrel{4}{4.1 \pm 2.0^{*}}$ & $\begin{array}{l}p=0.0206 \\
p=0.0049\end{array}$ \\
\hline $\begin{array}{l}\text { FOOD CONSUMPTION } \\
\text { n Trealed }\end{array}$ & 10 & 10 & 9 & 9 & \\
\hline $\begin{array}{l}\text { Grams per day } \\
\text { SD 0-4 } \\
\text { SD } 4-8 \\
\text { SD } 8-12 \\
\text { SD } 17-20 \\
\text { SD 20-24 } \\
\text { SD 24-28 }\end{array}$ & $\begin{array}{l}15.9 \pm 0.8^{4} \\
15.8 \pm 0.5 \\
15.7 \pm 0.5 \\
17.9 \pm 0.6 \\
19.4 \pm 0.5 \\
19.9 \pm 0.5\end{array}$ & $\begin{array}{l}14.3 \pm 0.5 \\
14.9 \pm 1.1 \\
17.1 \pm 1.0 \\
17.7 \pm 0.5 \\
18.4 \pm 0.7 \\
18.2 \pm 0.8\end{array}$ & $\begin{array}{l}14.6 \pm 1.4 \\
14.0 \pm 1.2 \\
15.6 \pm 1.1 \\
20.5 \pm 1.1 * \\
18.6 \pm 0.3 \\
19.3 \pm 0.5\end{array}$ & $\begin{array}{r}11.8 \pm 1.3^{*} \\
9.1 \pm 0.5^{*} \\
9.4 \pm 0.8^{*} \\
14.0 \pm 1.5^{*} \\
13.3 \pm 1.0^{*} \\
13.6 \pm 1.0^{*}\end{array}$ & $\begin{array}{l}p=0.0008 \\
p=0.00004 \\
p=0.0012 \\
p=0.0015^{\dagger} \\
p=0.0001 \\
p=0.0012\end{array}$ \\
\hline $\begin{array}{l}\text { BW Change }(g) \\
\text { SD } 0-28\end{array}$ & $73.3 \pm 3.8$ & $61.3 \pm 7.2$ & $53.2 \pm 3.4^{*}$ & $8.9 \pm 9.7 *$ & $p=0.00002$ \\
\hline
\end{tabular}

\& SEM

Fonaterel died during expoesure

"peo.0s cormpared to contude

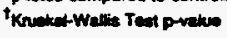


Table A.7

\section{GROUP 3}

Gestational Exposure

Female Sprague Dawley Rats

\begin{tabular}{|c|c|c|c|c|c|}
\hline & \multicolumn{4}{|c|}{ COPPER GALLIUM DISELENIDE (mg/kg/day) } & \multirow[b]{2}{*}{ Trend } \\
\hline & 0 & 30 & 100 & 250 & \\
\hline $\begin{array}{c}\text { FERTILITY AND NECROPSY } \\
\text { Females } \\
\text { Pregnant/Treated }\end{array}$ & $7 / 41$ & $8 / 12$ & $10 / 12$ & $10 / 12$ & \\
\hline $\begin{array}{l}\text { BW Change (g) } \\
\text { GD 6-15 } \\
\text { GD } 0.15\end{array}$ & $\begin{array}{l}39.9 \pm 2.7^{*} \\
66.2 \pm 3.8\end{array}$ & $\begin{array}{l}32.3 \pm 2.8 \\
57.6 \pm 3.5\end{array}$ & $\begin{array}{l}39.7 \pm 3.0 \\
64.9 \pm 2.6\end{array}$ & $\begin{array}{l}-2.3 \pm 4.2^{*} \\
23.9 \pm 4.4^{*}\end{array}$ & $\begin{array}{l}p=0.0004 \\
p=0.0002\end{array}$ \\
\hline $\begin{array}{l}\text { BW PND } 1 \text { (g) } \\
\text { BW PND } 4 \text { (g) }\end{array}$ & $\begin{array}{l}272.5 \pm 7.4 \\
280.3 \pm 8.9\end{array}$ & $\begin{array}{l}257.6 \pm 7.1 \\
264.7 \pm 4.7\end{array}$ & $\begin{array}{l}257.7 \pm 6.9 \\
271.2 \pm 8.8\end{array}$ & $\begin{array}{l}217.9 \pm 11.1^{*} \\
225.9 \pm 8.1^{*}\end{array}$ & $\begin{array}{l}p=0.0008 \\
p=0.0003\end{array}$ \\
\hline $\begin{array}{l}\text { BW Change (g) } \\
\text { PND 1-4 }\end{array}$ & $7.8 \pm 4.8$ & $7.1 \pm 2.2$ & $13.5 \pm 2.7$ & $8.6 \pm 2.8$ & $p=0.4508$ \\
\hline $\begin{array}{l}\text { Neonates } \\
\text { PND o } \\
\text { n Live } \\
\text { n Dead }\end{array}$ & $\begin{array}{r}13.9 \pm 0.9 \\
0.1 \pm 0.1\end{array}$ & $\begin{aligned} 10.6 & \pm 1.6 \\
0.2 & \pm 0.2\end{aligned}$ & $\begin{array}{c}12.8 \pm 0.6 \\
0\end{array}$ & $\begin{array}{l}9.4 \pm 1.4 \\
0.7 \pm 0.3\end{array}$ & $\begin{array}{l}p=0.0598 \\
p=0.1584\end{array}$ \\
\hline $\begin{array}{l}\text { PND } 1 \\
\text { n Live } \\
\text { n Dead }\end{array}$ & $\begin{aligned} 13.7 & \pm 0.8 \\
0.1 & \pm 0.1\end{aligned}$ & $\begin{array}{c}10.6 \pm 1.6 \\
0\end{array}$ & $\begin{aligned} 12.7 & \pm 0.6 \\
0.1 & \pm 0.1\end{aligned}$ & $\begin{array}{l}9.1 \pm 1.4 \\
0.3 \pm 0.3\end{array}$ & $\begin{array}{l}p=0.0521 \\
p=0.8697\end{array}$ \\
\hline $\begin{array}{l}\text { PND } 4 \\
\text { n Live } \\
\text { n Dead }\end{array}$ & $\begin{array}{r}13.6 \pm 0.8 \\
0.1 \pm 0.1\end{array}$ & $\begin{array}{c}10.6 \pm 1.6 \\
0\end{array}$ & $12.7 \pm 0.6$ & $\begin{array}{l}8.8 \pm 1.5 \\
0.3 \pm 0.2\end{array}$ & $\begin{array}{l}p=0.0510 \\
p=0.4658\end{array}$ \\
\hline $\begin{array}{l}\text { Mean Body Weight (g } \\
\text { PND } 1 \\
\text { PND } 4\end{array}$ & $\begin{array}{l}6.5 \pm 0.04 \\
9.5 \pm 0.1\end{array}$ & $\begin{array}{r}7.2 \pm 0.2^{*} \\
10.3 \pm 0.3^{*}\end{array}$ & $\begin{array}{l}7.1 \pm 0.2 \\
9.8 \pm 0.4\end{array}$ & $\begin{array}{l}5.6 \pm 0.3 \\
8.1 \pm 0.5\end{array}$ & $\begin{array}{l}p=0.0018^{\dagger} \\
p=0.0180^{\dagger}\end{array}$ \\
\hline n Implantation Sites & $14.7 \pm 0.9$ & $11.9 \pm 1.5$ & $15.1 \pm 0.7$ & $14.0 \pm 0.6$ & $p \approx 0.8079$ \\
\hline $\begin{array}{l}\text { FOOD CONSUMPTION } \\
\mathrm{n} \text { Treated }\end{array}$ & 11 & 12 & 12 & 12 & \\
\hline $\begin{array}{c}\text { Grams per day } \\
\text { GD 6-8 } \\
\text { GD 8-10 } \\
\text { GD } 10-12 \\
\text { GD } 12-14\end{array}$ & $\begin{array}{l}18.3 \pm 1.0^{2} \\
18.7 \pm 1.0 \\
19.3 \pm 0.8 \\
18.9 \pm 1.1\end{array}$ & $\begin{array}{l}15.8 \pm 0.8 \\
17.4 \pm 1.0 \\
17.6 \pm 0.9 \\
17.8 \pm 1.0\end{array}$ & $\begin{array}{l}17.3 \pm 0.9 \\
18.4 \pm 0.7 \\
18.9 \pm 1.0 \\
17.9 \pm 1.0\end{array}$ & $\begin{array}{l}13.6 \pm 0.8^{*} \\
11.8 \pm 1.1^{*} \\
12.1 \pm 1.2^{*} \\
12.4 \pm 1.3^{*}\end{array}$ & $\begin{array}{l}p=0.0051 \\
p=0.0001 \\
p=0.0003 \\
p=0.0013\end{array}$ \\
\hline $\begin{array}{l}\text { BW Change (g) } \\
\text { GD } 6-15\end{array}$ & $39.9 \pm 2.7$ & $32.3 \pm 2.8$ & $39.7 \pm 3.0$ & $-2.3 \pm 4.2^{*}$ & $p=0.0004$ \\
\hline
\end{tabular}

Amen * SeM

tpro.05 complarad lo controta

TKrever-Wase Teet p-value 
Male Sprague Dawley Rats

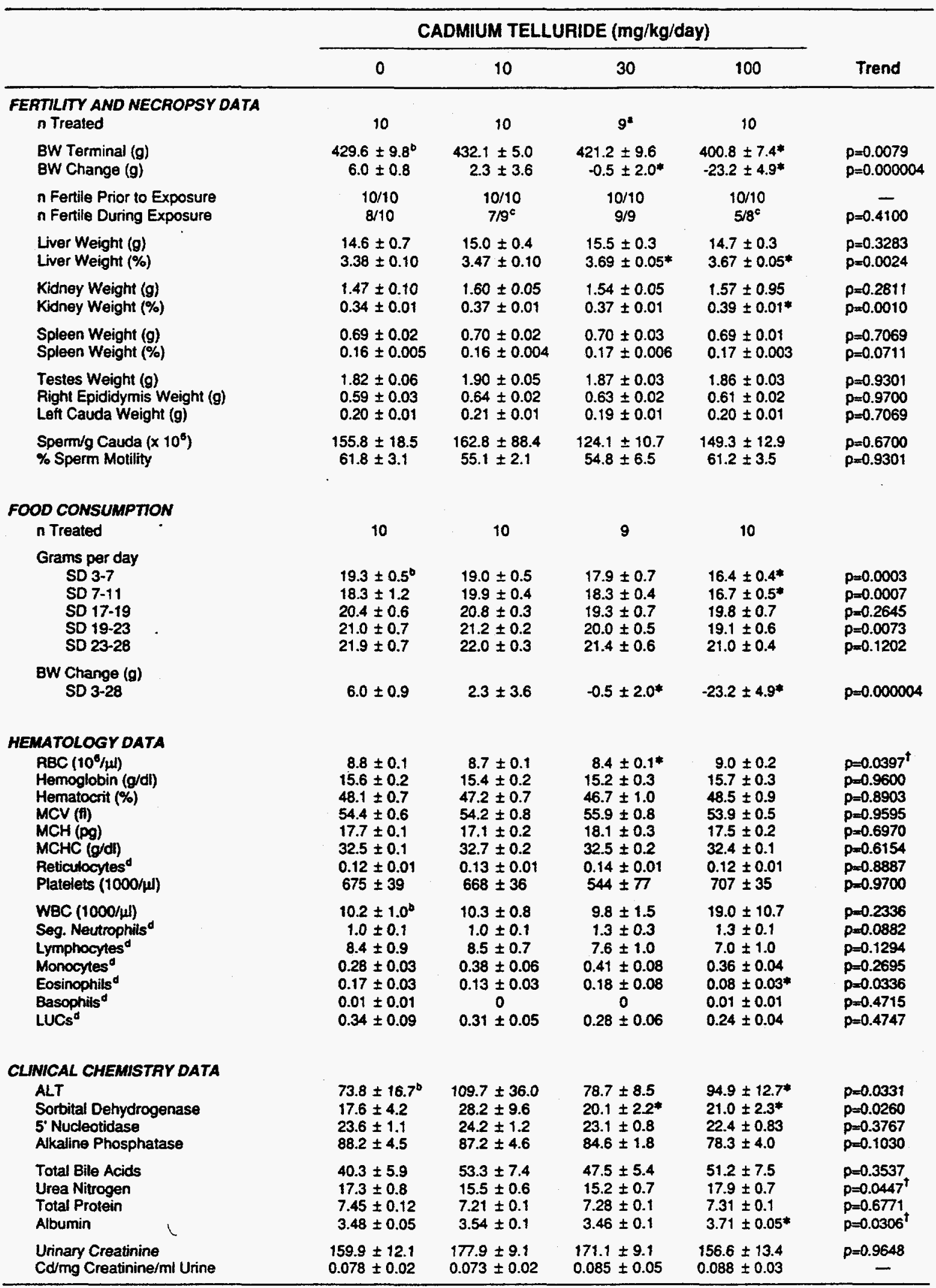

- Oru mato died dering dowing

maen a SEM

cFomales died prior to mating

- Omerentials expressed es absolute valuea

- peo. os compares to controls

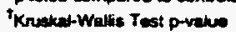


Table A. 9

\section{GROUP 2}

\section{Continuous Exposure}

Female Sprague Dawley Rats

\begin{tabular}{|c|c|c|c|c|c|}
\hline & \multicolumn{4}{|c|}{ CADMIUM TELLURIDE (mg/kg/day) } & \multirow[b]{2}{*}{ Trend } \\
\hline & 0 & 10 & 30 & 100 & \\
\hline $\begin{array}{l}\text { FERTILITY AND NECROPSY DATA } \\
\text { n Treated }\end{array}$ & 10 & 10 & 10 & 10 & \\
\hline BW Change SD 0.28 (g) & $76.9 \pm 8.1$ & $55.4 \pm 7.2$ & $56.5 \pm 5.4$ & $33.8 \pm 4.4^{*}$ & $p=0.0018$ \\
\hline PregnantTreated & $8 / 10$ & $7 / 9$ & $9 / 9^{b}$ & $5 / 8^{c}$ & $p=0.4100$ \\
\hline$n$ Live Implants & $10.5 \pm 1.8$ & $11.7 \pm 1.5$ & $13.2 \pm 1.1$ & $11.0 \pm 0.6$ & $p=0.8509$ \\
\hline $\begin{array}{l}\text { Early Resorptions } \\
\text { Late Resorptions }\end{array}$ & $\underset{0}{0.5 \pm 0.3}$ & $0.1 \pm 0.1$ & $0.2 \pm 0.1$ & $1.0 \pm 0.3$ & $p=0.2705$ \\
\hline $\begin{array}{l}\text { Total Implants } \\
\text { Corpora Lutea }\end{array}$ & $\begin{array}{l}11.0 \pm 1.8 \\
13.9 \pm 0.8\end{array}$ & $\begin{array}{l}11.9 \pm 1.6 \\
15.4 \pm 0.8\end{array}$ & $\begin{array}{l}13.4 \pm 1.1 \\
15.8 \pm 0.4\end{array}$ & $\begin{array}{l}12.0 \pm 0.4 \\
14.5 \pm 0.8\end{array}$ & $\begin{array}{l}p=0.7644 \\
p=0.5803\end{array}$ \\
\hline $\begin{array}{l}\text { FOOD CONSUMPTION } \\
\text { n Treated }\end{array}$ & 10 & 9 & 10 & $10^{c}$ & \\
\hline $\begin{array}{c}\text { Grams per day } \\
\text { SD 0-4 } \\
\text { SD 4-8 } \\
\text { SD 8-12 } \\
\text { SD 17-20 } \\
\text { SD 20-24 } \\
\text { SD 24-28 }\end{array}$ & $\begin{array}{l}12.9 \pm 0.4^{4} \\
14.9 \pm 0.5 \\
15.2 \pm 0.3 \\
19.5 \pm 0.6 \\
18.7 \pm 0.6 \\
21.0 \pm 0.6\end{array}$ & $\begin{array}{l}11.9 \pm 1.1 \\
14.3 \pm 0.4 \\
14.8 \pm 0.5 \\
18.4 \pm 0.6 \\
17.7 \pm 0.7 \\
18.8 \pm 0.8 *\end{array}$ & $\begin{array}{l}12.3 \pm 0.4 \\
14.7 \pm 0.4 \\
14.6 \pm 0.2 \\
19.0 \pm 0.3 \\
17.2 \pm 0.4 \\
19.5 \pm 0.4^{*}\end{array}$ & $\begin{array}{l}10.7 \pm 0.5^{*} \\
12.4 \pm 0.7^{*} \\
12.8 \pm 0.6^{*} \\
16.0 \pm 0.4^{*} \\
15.9 \pm 0.4^{*} \\
18.2 \pm 0.3^{*}\end{array}$ & $\begin{array}{l}p=0.0117 \\
p=0.0104 \\
p=0.0023 \\
p=0.0089 \\
p=0.0046 \\
p=0.0122\end{array}$ \\
\hline $\begin{array}{l}\text { BW Change (g) } \\
\text { SD } 0-28\end{array}$ & $76.9 \pm 8.1$ & $55.4 \pm 7.2$ & $56.5 \pm 5.4$ & $33.8 \pm 4.4^{*}$ & $p=0.0018$ \\
\hline
\end{tabular}

"One mals died prior to methy

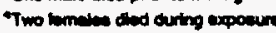

-polos compered to controle 
Table A.10

GROUP 3

Gestational Exposure

Female Sprague Dawley Rats

\begin{tabular}{|c|c|c|c|c|c|}
\hline & \multicolumn{4}{|c|}{ CADMIUM TELLURIDE (mg/kg/day) } & \multirow[b]{2}{*}{ Trend } \\
\hline & 0 & 10 & 30 & 100 & \\
\hline $\begin{array}{l}\text { FEATILTY AND NECROPSY DATA } \\
\text { Females }\end{array}$ & & & & & . \\
\hline Pregnant/Treated & $12 / 13$ & $10 / 11$ & $12 / 12$ & $10 / 10$ & \\
\hline $\begin{array}{c}\text { BW Change }(g) \\
\text { GD } 6-15 \\
\text { GD } 0-15\end{array}$ & $\begin{array}{l}42.3 \pm 2.7^{a} \\
66.6 \pm 2.7\end{array}$ & $\begin{array}{l}28.7 \pm 8.5 \\
54.1 \pm 7.5\end{array}$ & $\begin{array}{l}33.4 \pm 1.1^{*} \\
56.4 \pm 2.5^{*}\end{array}$ & $\begin{array}{l}19.2 \pm 3.9^{*} \\
42.3 \pm 6.0^{*}\end{array}$ & $\begin{array}{l}p=0.000009 \\
p=0.00004\end{array}$ \\
\hline $\begin{array}{l}\text { BW PND } 1(g) \\
\text { BW PND } 4(g)\end{array}$ & $\begin{array}{l}273.2 \pm 6.6 \\
284.5 \pm 6.0\end{array}$ & $\begin{array}{l}266.5 \pm 5.3 \\
275.4 \pm 5.7\end{array}$ & $\begin{array}{l}250.4 \pm 4.3^{\star} \\
260.6 \pm 6.2^{*}\end{array}$ & $\begin{array}{l}232.0 \pm 6.9^{*} \\
249.9 \pm 7.2^{*}\end{array}$ & $\begin{array}{l}p=0.00002 \\
p=0.0002\end{array}$ \\
\hline $\begin{array}{l}\text { BW Change }(g) \\
\text { PND 1-4 }\end{array}$ & $13.9 \pm 2.0$ & $10.8 \pm 2.1$ & $10.2 \pm 4.1$ & $17.9 \pm 3.6$ & $p=0.4695$ \\
\hline $\begin{array}{l}\text { Neonates } \\
\text { PND 0 } \\
\text { n Live } \\
\text { n Dead }\end{array}$ & $\begin{array}{r}12.8 \pm 0.7 \\
0.3 \pm 0.2\end{array}$ & $\begin{array}{r}10.6 \pm 1.0 \\
0.1 \pm 0.1\end{array}$ & $\begin{array}{r}11.8 \pm 0.9 \\
0.6 \pm 0.3\end{array}$ & $\begin{array}{r}12.3 \pm 0.6 \\
1.0 \pm 0.6\end{array}$ & $\begin{array}{l}p=0.6161 \\
p=0.3116\end{array}$ \\
\hline $\begin{array}{l}\text { PND } 1 \\
\text { n Live } \\
\text { n Dead }\end{array}$ & $\begin{array}{r}12.7 \pm 0.7 \\
0.1 \pm 0.1\end{array}$ & $10.6 \pm 1.0$ & $\begin{array}{r}11.6 \pm 0.9 \\
0.2 \pm 0.1\end{array}$ & $\begin{array}{r}12.1 \pm 0.6 \\
0.2 \pm 0.1\end{array}$ & $\begin{array}{l}p=0.5520 \\
p=0.3945\end{array}$ \\
\hline $\begin{array}{l}\text { PND } 4 \\
\text { n Live } \\
\text { n Dead }\end{array}$ & $12.7 \pm 0.7$ & $\begin{array}{c}10.5 \pm 0.9 \\
0\end{array}$ & $\begin{array}{r}11.5 \pm 0.9 \\
0.1 \pm 0.1\end{array}$ & $\begin{array}{r}12.0 \pm 0.6 \\
0.1 \pm 0.1\end{array}$ & $\begin{array}{l}p=0.4998 \\
p=0.2905\end{array}$ \\
\hline $\begin{array}{l}\text { Mean Body Weight (g) } \\
\text { PND } 1 \\
\text { PND } 4\end{array}$ & $\begin{array}{r}6.8 \pm 0.2 \\
10.0 \pm 0.4\end{array}$ & $\begin{array}{r}7.1 \pm 0.2 \\
10.5 \pm 0.3\end{array}$ & $\begin{array}{r}7.0 \pm 0.2 \\
10.2 \pm 0.5\end{array}$ & $\begin{array}{l}6.5 \pm 0.2 \\
9.1 \pm 0.4\end{array}$ & $\begin{array}{l}p=0.5362 \\
p=0.2468\end{array}$ \\
\hline n Implantation Sites & $13.9 \pm 0.8$ & $13.3 \pm 0.6$ & $13.9 \pm 0.6$ & $14.0 \pm 0.3$ & $p=0.9113$ \\
\hline FOOD CONSUMPTION & & & & . & \\
\hline n Treated & 13 & 11 & 12 & 10 & \\
\hline $\begin{array}{l}\text { Grams per day } \\
\text { GD 6-8 } \\
\text { GD 8-10 } \\
\text { GD 10-12 } \\
\text { GD 12-14 }\end{array}$ & $\begin{array}{l}19.9 \pm 0.9^{\star} \\
20.0 \pm 0.3 \\
21.1 \pm 0.5 \\
20.2 \pm 1.1\end{array}$ & $\begin{array}{l}19.1 \pm 1.4 \\
19.5 \pm 1.1 \\
19.3 \pm 1.0 \\
18.7 \pm 1.1\end{array}$ & $\begin{array}{l}19.1 \pm 0.8 \\
18.6 \pm 0.6^{*} \\
18.9 \pm 0.8^{*} \\
20.4 \pm 0.8\end{array}$ & $\begin{array}{l}16.6 \pm 0.9^{*} \\
17.3 \pm 0.8^{*} \\
17.0 \pm 0.5^{\star} \\
15.4 \pm 1.2^{*}\end{array}$ & $\begin{array}{l}p=0.0246 \\
p=0.0039 \\
p=0.0001 \\
p=0.0045\end{array}$ \\
\hline $\begin{array}{c}\text { BW Change (g) } \\
\text { GD } 6-15\end{array}$ & $42.3 \pm 5.2$ & $28.7 \pm 8.5$ & $33.4 \pm 1.1 *$ & $19.2 \pm 3.9^{*}$ & $\rho=0.00001$ \\
\hline
\end{tabular}

Meen ₹ SaM

peco.05 compered to controls 
Appendix B Estimation of Reference Dose (RfD) 


\section{Table B1. Estimation of Reference Dose (RfD) for Non-carcinogens, with Example Calculations based on CdTe (1)}

\begin{tabular}{ll}
\hline Factor & Standard Uncertainty Factors (UF) - US EPA Reference Dose RID) Work Group \\
\hline $\begin{array}{l}\text { 10H - Sensitivity in } \\
\text { Humans }\end{array}$ & $\begin{array}{l}\text { Use factor of } 10 \text { when extrapolating from valid experimental results in studies using prolonged } \\
\text { exposure to average healthy humans. Intended to account for a variation in the sensitivity among } \\
\text { the members of the human population. }\end{array}$ \\
$\begin{array}{l}\text { 10A - Animal to Man } \\
\text { 10S - Sub- chronic to } \\
\text { Chronic }\end{array}$ & $\begin{array}{l}\text { Additional factor of } 10 \text { when extrapolation from valid results of long-term studies on experimental } \\
\text { animals when results of studies of human exposure are not available or are inadequate. Uncertainty }\end{array}$ \\
& $\begin{array}{l}\text { Additional factor of } 10 \text { for uncertainty when extrapolating from less than chronic results on } \\
\text { experimental animals, when there is no useful long-tern human data. Designed for extrapolation } \\
\text { from sub-chronic No Observed Adverse Efrect Levels (NOAEL) to chronic NOAEL. }\end{array}$ \\
10L - Extrapolation & $\begin{array}{l}\text { Additional factor of } 10 \text { for uncertainty when RID is derived from a LOAEL instead of a NOAEL. } \\
\text { Intended to account for inherent uncertainty when extrapolating a NOAEL from a LOAEL. }\end{array}$ \\
\hline
\end{tabular}

Modifying Factors (MF)

For professional judgment, to determine an additional uncertainty factor that is greater than 0 but less than 10 . The magnitude of the MF depends on the professional assessment of scientific uncertainties of the study not explicitly treated in UF factors $10 \mathrm{H}-10 \mathrm{~L}$. Default value is 1 . This includes completeness of database, no. of species tested, species sensitivity.

\section{Relevant Definitions}

RfD -reference dose An estimate (with uncertainty spanning perhaps an order of magnitude) of a daily exposure to the human population (including sensitive sub-groups) that is likely to be without appreciable risk of deleterious effects during a lifetime.

NOAEL

No observed adverse effect level - An experimentally determined dose at which no statistically or biologically significant indication of the toxic effect of concern is observed.

LOAEL

Lowest observed adverse effect level - The lowest experimentally determined dose at which a statistically or biologically significant indication of the toxic effect of concern is observed

\section{Calculation of Estimate Oral RfD for CdTe}

Data

Sub - chronic 28 day exposure on single animal species. Rapid reproductive and developmental screen included. Control and three levels of dose with approximately 10 animals per dose level. Systemic toxicity determined in only one sex-males. Dose administered daily by oral gavage. Upper dose at or near maximally tolerated exposure. Dose levels $0,10,30,100 \mathrm{mg} / \mathrm{kg} /$ day.

Results No evidence of reproductive effects at any dose, significant changes in body weight in males and females at 30 , and $100 \mathrm{mgs}$, but exposure is also associated with reduced food consumption. Target end-points: increase in liver wt. in males, statistically significant differences in two enzyme systems and increased albumin all at $100 \mathrm{mgs}$. NOAEL $=30 \mathrm{mgs}$, LOAEL $=100 \mathrm{mgs}$.

RID-(LOAEL) LOAEL $(10 \mathrm{H} \times 10 \mathrm{~A} \times 10 \mathrm{~S} \times 10 \mathrm{~L})(\mathrm{MF}=2)$

$\mathrm{RID}=(100 \mathrm{mg} / \mathrm{kg} /$ day $) /(10,000 \times 2)=5 \times 10^{-3} \mathrm{mg} / \mathrm{kg} /$ day

If $\mathrm{MF}=10$ 


$$
\mathrm{RD}=(100 \mathrm{mg} / \mathrm{kg} / \text { day }) /(10,000 \times 10)=1 \times 10^{-3} \mathrm{mg} / \mathrm{kg} / \text { day }
$$

Modifying Factors: Sub-chronic extrapolation should be from a 90 day study, only males included in systemic tox screen. Thus a modifying factor of 2 is included as base for all compounds. A more conservative modifying factor may be chosen. LOAEL used to account for small number of animal $s$ which biases towards no adverse effects. 
Summary systemic toxicity used to establish Lowest Observed Adverse Effect Level (LOAEL) from 28 day range finding study.

\begin{tabular}{|c|c|}
\hline and & ing factor (MF) Applied to LOAEL \\
\hline $\begin{array}{l}\text { CIS } \\
\text { NOAEL - } \\
100 \mathrm{mg} / \mathrm{kg} / \mathrm{day} \\
\text { LOAEL - } \\
250 \mathrm{mg} / \mathrm{kg} / \mathrm{day}\end{array}$ & $\begin{array}{l}\text { Small but statistically significant increase in male liver weights (absolute and relative, without } \\
\text { corresponding changes in enzyme levels. Significant weight loss in females at highest dose. } \\
\text { Suspect, but not statistically significant deficit in live and total implants relative to controls ( } 25 \% \\
\text { deficit in live pups). Nonstatistically significant, but borderline deficit in male fertility. } \\
\text { Modify Factor: A factor of } 3 \text { incorporated into estimate of RfD to account for uncertainty in } \\
\text { assessment of male fertility and deficit in number of live pups in main study. Systemic tox. in only } \\
\text { one sex. }\end{array}$ \\
\hline $\begin{array}{l}\text { CGS } \\
\text { NOAEL - } \\
30 \mathrm{mg} / \mathrm{kg} / \mathrm{day} \\
\text { LOAEL - } \\
100 \mathrm{mg} / \mathrm{kg} / \mathrm{day}\end{array}$ & $\begin{array}{l}\text { Increased liver weight manifest in males at } 100 \mathrm{mg} \text { accompanied by highly statistically significant } \\
\text { dose-response. Statistically significant deficit in live implants at a dose of } 100 \mathrm{mgs} \text { and greater. } \\
\text { Data clearly indicate reproductive deficits, possibly associated with reduced ovulation. Reproductive } \\
\text { effects in males cannot be discounted. Clear reduction in male fertility at } 250 \mathrm{mgs} \text { in terms of } \\
\text { females impregnated, and statistically significant decline in total sperm count at same dose. } \\
\text { Modifying Factor: Uncertainty factor of five is included to account for severity of reproductive } \\
\text { effects seen at } 100 \text { mgs and the relatively small difference in dose differential between } 100 \text { and } 250 \\
\text { mgs where effects were severe. Uncertainty factor could be as large as ten given the severity of } \\
\text { effect. }\end{array}$ \\
\hline $\begin{array}{l}\text { CdTe } \\
\text { NOAEL - } \\
30 \mathrm{mg} / \mathrm{kg} / \text { day } \\
\text { LOAEL - } \\
100 \mathrm{mg} / \mathrm{kg} / \text { day }\end{array}$ & $\begin{array}{l}\text { At maximum exposure ( } 100 \mathrm{mgs} \text { ) albumin level was statistically elevated over controls, as was the } \\
\text { relative liver weight in male animals. Serum enzymes were slightly elevated at maximum exposure. } \\
\text { In both male and female rats there was a clear deficit in weight gain. Note: Except for effects on } \\
\text { body weight, target effects were relatively benign. Reproductive affects were not apparent. } \\
\text { Modifying Factor: Factor of } 2 \text { to account for systemic tox in one sex. }\end{array}$ \\
\hline
\end{tabular}

Table B3. Estimated Oral Reference Dose (RfD) for CIS, CGS, and CdTe, using Standard Uncertainty Factors (UF)

\begin{tabular}{lllll}
\hline Compound & LOAEL $(\mathrm{mg} / \mathrm{kg} / \mathrm{day})$ & UF $\times$ MF & $\begin{array}{l}\text { RFD } \\
(\mathrm{mg} / \mathrm{kg} / \text { day })\end{array}$ & $\begin{array}{l}\text { Projected } \\
\text { Intake }(70 \mathrm{Kg} \text { man) }\end{array}$ \\
\hline CIS & 250 & $10,000 \times 3$ & 0.0083 & 0.581 \\
CGS & 100 & $10,000 \times 5$ & 0.002 & 0.14 \\
CdTe & 100 & $10,000 \times 2$ & 0.005 & 0.35
\end{tabular}


Table B4

Element-Specific Oral Reference Dose Projected from RfD's for Specific Compounds

\begin{tabular}{lll}
\hline Compound & Element & Projected Oral RfD (mg/kg/day) \\
\hline & Copper & $1.6 \times 10^{-3}$ \\
CIS & Indium & $2.9 \times 10^{-3}$ \\
& Selenium & $3.9 \times 10^{-3}$ \\
CGS & Copper & $4.4 \times 10^{-3}$ \\
& Gallium & $4.8 \times 10^{-3}$ \\
& Selenium & $1.1 \times 10^{-3}$ \\
& & \\
CdTe & Cadmium & $2.4 \times 10^{-3}$ \\
& Tellurium & $2.7 \times 10^{-3}$
\end{tabular}




\section{APPENDIX C - GLOSSARY OF COMMON TOXICOLOGY/RISK ASSESSMENT TERMS}

The following are some common toxicity terminology necessary for understanding risk assessment;

- Dose: The amount of substance entering the body (of the test animal, the worker, etc.). Can be expressed in mass of substance per mass of body weight (e.g., mg/kg, where "mg" represents the amount of substance administered per $\mathrm{kg}$ of body weight of the test animal) or as a concentration $(\mathrm{mg} / \mathrm{m} 3)$.

- LCx or LDx The lowest lethal concentration or dose of a substance which has been reported to cause death in test animals. $\mathrm{X}$ represents the percentage of the animals affected.

- Effect and response: Terms that are usually interchangeably used to describe biological change in either an individual or population associated with an exposure or dose. Some toxicologists apply the term "effect" to a biological change and the term "response" to the proportion of the population that demonstrates a defined effect (Pfitzer, 1976 cited in WHO 1978)

- Response: Usually means the incidence rate of an effect, for example, the LD50 (lethal dose 50\%) describes the dose expected to cause $50 \%$ response in a population tested for the lethal effect of a chemical.

- Acute Effects: Effects that occur or develop rapidly after a single administration, but may appear after repeated or prolonged exposure.

- Chronic effects: May result from a single exposure but usually are a result of repeated or prolonged exposure . They may arise from the accumulation of a toxic substance or its metabolite in the body, or from a summation of acute effects.

- Dose-effect curves: Relation between dose and the magnitude of a dreaded effect., the curve may be linear within a given dose range but, generally, is not.

- Dose-response curves: Relationship between dose and the proportion of individuals responding with a quantal effect.

- Dose-Response: The characteristics of exposure and the spectrum of effects come together in a correlative relation usually referred to as sthe dose response relationship. In toxicology determination of the median lethal dose (LD50) is usually the first experiment performed with a new chemical.

Threshold dose: Minimal effect that any chemical causes 